\title{
Recent Developments in the Use of Kinase Inhibitors for Management of Viral Infections
}

\author{
Rinky Raghuvanshi ${ }^{\dagger \dagger}$ and Sandip B. Bharate ${ }^{\dagger+*}$
}

${ }^{\dagger}$ Medicinal Chemistry Division, CSIR-Indian Institute of Integrative Medicine, Canal Road, Jammu-180001, India

${ }^{\ddagger}$ Academy of Scientific \& Innovative Research, Ghaziabad-201002, India

*Corresponding author. Email: sbharate@iiim.res.in

\section{CONTENTS:}

Figure S1. Chemical structures of approved or clinical stage JAK inhibitors that are not yet been tested for antiviral activity.

Table S1. In vitro antiviral activity and cellular cytotoxicity of kinase inhibitors 1-99 


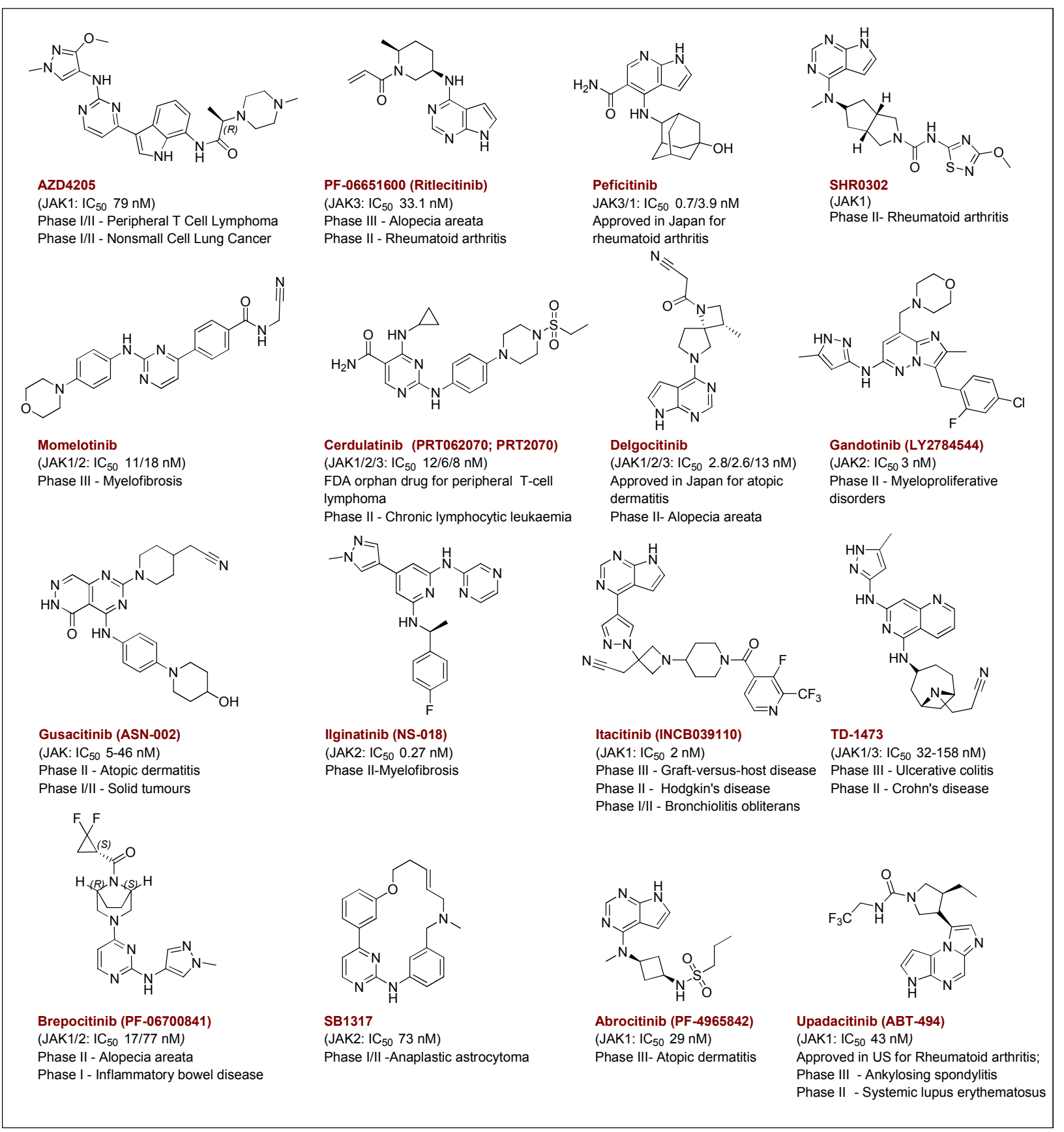

Figure S1. Chemical structures of approved or clinical stage JAK inhibitors that are not yet been tested for antiviral activity. The chemical structures of AZD0449 and Jakotinib are not available in the literature. 
Table S1. In vitro antiviral activity and cellular cytotoxicity of kinase inhibitors 1-99

\begin{tabular}{|c|c|c|c|c|c|}
\hline \multirow[t]{2}{*}{ Kinase inhibitor } & \multicolumn{4}{|c|}{ In vitro antiviral activity $\&$ cytotoxicity in cellular systems } & \multirow{2}{*}{$\begin{array}{l}\text { Cellular toxicity } \\
\text { in other cell } \\
\text { systems (wherever } \\
\text { the cytotoxicity } \\
\text { information is not } \\
\text { available in assay system } \\
\text { used for antiviral } \\
\text { activity) } \\
\text { Cell line \& } \mathbf{C C}_{\mathbf{5 0}}\end{array}$} \\
\hline & Virus & Assay system & $\begin{array}{l}\text { Antiviral activity } \\
\text { value }\left(\mathrm{EC}_{50} / \mathrm{IC}_{50}\right)\end{array}$ & $\begin{array}{l}\text { Cytotoxicity } \\
\left(\text { Cell line \& } \mathrm{CC}_{50}\right)\end{array}$ & \\
\hline CND3514 (1) & CHIKV & Resazurin reduction assay in Huh-7 cells & $\mathrm{EC}_{50} 2.2 \mu \mathrm{M}^{1}$ & Huh-7: $\mathrm{CC}_{50}>50 \mu \mathrm{M}^{1}$ & \\
\hline CND1201 (2) & $\begin{array}{l}\text { DENV1/ } \\
\text { DENV2/ } \\
\text { DENV3/ } \\
\text { DENV4 }\end{array}$ & Assay performed in Huh-7.5 cells & $\begin{array}{l}\mathrm{EC}_{50} 0.9 / 7.6 / 2.6 / 5.0 \\
\mu \mathrm{M}^{2}\end{array}$ & $\begin{array}{l}\text { Huh 7.5: } \mathrm{CC}_{50}>100 \\
\mu \mathrm{M}^{2}\end{array}$ & \\
\hline BIBU 1361 (3) & DENV E & Immunostaining in HEK293 cells & $\mathrm{IC}_{50} 0.90 \mu \mathrm{M}^{3}$ & $\begin{array}{l}\text { HEK293: Nontoxic @ } \\
10 \mu \mathrm{M}^{3}\end{array}$ & \\
\hline & DENV-2 & Assay performed in Huh-7.5 cells & $\mathrm{EC}_{50} 4.33 \mu \mathrm{M}^{2}$ & $\begin{array}{l}\text { Huh-7.5: } \mathrm{CC}_{50} 4.49 \\
\mu \mathrm{M}^{2}\end{array}$ & \\
\hline H-89 (4) & DENV E & Immunostaining in HEK293 cells & $\mathrm{IC}_{50} 0.96 \mu \mathrm{M}^{3}$ & $\begin{array}{l}\text { HEK293: Nontoxic @ } \\
10 \mu \mathrm{M}^{3}\end{array}$ & \\
\hline
\end{tabular}




\begin{tabular}{|c|c|c|c|c|}
\hline 5 & HSV-1 & Plaque assay in HFL1 cells & $\mathrm{EC}_{50} 32 \mu \mathrm{M}^{4}$ & HFL1: $\mathrm{CC}_{50} 159 \mu \mathrm{M}^{4}$ \\
\hline 6 & HSV-1 & Plaque assay in HFL1 cells & $\mathrm{EC}_{50} 29 \mu \mathrm{M}^{4}$ & HFL1: $\mathrm{CC}_{50} 1410 \mu \mathrm{M}^{4}$ \\
\hline 7 & HSV-1 & Plaque assay in HFL1 cells & $\mathrm{EC}_{50} 64 \mu \mathrm{M}^{4}$ & HFL1: $\mathrm{CC}_{50} 2044 \mu \mathrm{M}^{4}$ \\
\hline PHA-690509 (8) & ZIKV & Focus forming assay in Vero cells & $\mathrm{IC}_{50} 90 \mathrm{nM}^{5}$ & $\begin{array}{l}\text { Human astrocytes (BJ } \\
\text { line): } \mathrm{CC}_{50}>10 \mu \mathrm{M}^{5}\end{array}$ \\
\hline B9 (9) & HIV-1 & Assay performed in CEM T4 cells & $\mathrm{IC}_{50} 0.3 \mu \mathrm{M}^{6}$ & $\begin{array}{l}\text { CEM T4: } \mathrm{CC}_{50}>10 \\
\mu \mathrm{M}^{6}\end{array}$ \\
\hline $\begin{array}{l}\text { Dinaciclib (10, } \\
\text { SCH 727965) }\end{array}$ & $\begin{array}{l}\text { IAV H7N9/ } \\
\text { pdmH1N1/ } \\
\text { H3N2 IAV }\end{array}$ & Assay performed in A549 cells & $\mathrm{IC}_{50} 20 / 50 / 210 \mathrm{nM}^{7}$ & A549: $\mathrm{CC}_{50}>100 \mu \mathrm{M}^{7}$ \\
\hline \multirow{2}{*}{$\begin{array}{l}\text { Flavopiridol (11, } \\
\text { L86-8275, } \\
\text { HMR1275) }\end{array}$} & HIV-1 & $\begin{array}{l}\text { Single-round infection assays in Sx22-1 } \\
\text { cells }\end{array}$ & $\mathrm{IC}_{50}<10 \mathrm{nM}^{8}$ & $\begin{array}{l}\text { Sx22-1 cells: } \mathrm{CC}_{50} \\
>100 \mathrm{nM}^{8}\end{array}$ \\
\hline & $\begin{array}{l}\text { IAV H7N9/ } \\
\text { pdmH1N1/ } \\
\text { H3N2 }\end{array}$ & Assay performed in A549 cells & $\begin{array}{l}\mathrm{IC}_{50} 240 / 590 / 700 \\
\mathrm{nM}^{7}\end{array}$ & $\begin{array}{l}\text { A549: } \mathrm{CC}_{50}>100 \mu \mathrm{M}^{7} \\
(\mathrm{SI}>140)\end{array}$ \\
\hline PIK75 (12) & $\begin{array}{l}\text { IAV H7N9/ } \\
\text { pdmH1N1/ } \\
\text { H3N2 IAV }\end{array}$ & $\begin{array}{l}\text { Immunofluorescence staining assay in } \\
\text { A549 cells }\end{array}$ & $\mathrm{IC}_{50} 40 / 320 / 400 \mathrm{nM}^{7}$ & $\begin{array}{l}\text { A549: } \mathrm{CC}_{50}>100 \mu \mathrm{M}^{7} \\
(\mathrm{SI}>250)\end{array}$ \\
\hline Imatinib (13) & SARS-CoV & $\begin{array}{l}\text { Cytopathic effect (CPE) inhibition assay } \\
\text { in Vero E6 cells }\end{array}$ & $\mathrm{EC}_{50} 9.8 \mu \mathrm{M}^{9}$ & $\begin{array}{l}\text { Vero E6: } \mathrm{CC}_{50}>100 \\
\mu \mathrm{M} ;{ }^{9}\end{array}$ \\
\hline
\end{tabular}




\begin{tabular}{|c|c|c|c|c|}
\hline & MERS-CoV & $\begin{array}{l}\text { Cytopathic effect (CPE) inhibition assay } \\
\text { in Vero E6 cells }\end{array}$ & $\mathrm{EC}_{50} 17.6 \mu \mathrm{M}^{9}$ & $\begin{array}{l}\text { Vero E6: } \mathrm{CC}_{50}>100 \\
\mu \mathrm{M} ;{ }^{9}\end{array}$ \\
\hline \multirow[t]{3}{*}{ Apilimod (14) } & EBOV & $\begin{array}{l}\text { Chemiluminescent enzyme-linked } \\
\text { immunosorbent assay in Huh/Vero } \\
\text { E6/MDM cells }\end{array}$ & $\begin{array}{l}\mathrm{IC}_{50} 0.13 / 0.03 / 0.01 \\
\mu \mathrm{M}^{10}\end{array}$ & $\begin{array}{l}\text { Huh/Vero E6/MDM: } \\
\mathrm{CC}_{50}>1 \mu \mathrm{M}^{10}\end{array}$ \\
\hline & MARV & $\begin{array}{l}\text { Chemiluminescent enzyme-linked } \\
\text { immunosorbent assay in Huh/Vero } \\
\text { E6/MDM cells }\end{array}$ & $\begin{array}{l}\mathrm{IC}_{50} 0.14 / 0.01 / 0.01 \\
\mu \mathrm{M}^{10}\end{array}$ & $\begin{array}{l}\text { Huh/Vero E6/MDM: } \\
\mathrm{CC}_{50}>1 \mu \mathrm{M}^{10}\end{array}$ \\
\hline & SARS-CoV-2 & $\begin{array}{l}\text { Immunofluorescence assay in Vero E6 } \\
\text { cells }\end{array}$ & $\mathrm{EC}_{50} 23 \mathrm{nM}^{11}$ & $\begin{array}{l}\text { Vero E6: } \mathrm{CC}_{50}>100 \\
\mathrm{nM}^{11}\end{array}$ \\
\hline $\begin{array}{l}\text { Berzosertib (15, } \\
\text { VE-822) }\end{array}$ & SARS-CoV-2 & $\begin{array}{l}\text { Cytopathic effect (CPE) inhibition assay } \\
\text { inVero E6 cells }\end{array}$ & $\mathrm{EC}_{50} 4.28 \mathrm{nM}^{12}$ & $\begin{array}{l}\text { Vero E6: Nontoxic @ } \\
250 \mathrm{nM}^{12}\end{array}$ \\
\hline $\begin{array}{l}\text { Vistusertib (16, } \\
\text { AZD2014) }\end{array}$ & SARS-CoV-2 & $\begin{array}{l}\text { Cytopathic effect (CPE) inhibition assay } \\
\text { inVero E6 cells }\end{array}$ & $\mathrm{EC}_{50} 15.9 \mathrm{nM}^{12}$ & $\begin{array}{l}\text { Vero E6: Nontoxic @ } \\
250 \mathrm{nM}^{12}\end{array}$ \\
\hline $\begin{array}{l}\text { Nilotinib (17, } \\
\text { AMN-107) }\end{array}$ & SARS-CoV-2 & $\begin{array}{l}\text { Cytopathic effect (CPE) inhibition assay } \\
\text { in Vero E6 cells }\end{array}$ & $\mathrm{EC}_{50} 80 \mathrm{nM}^{12}$ & $\begin{array}{l}\text { Vero E6: } \mathrm{CC}_{50}>250 \\
\mathrm{nM}^{12}\end{array}$ \\
\hline Fedratinib (18) & SARS-CoV-2 & $\begin{array}{l}\text { Cytopathic effect (CPE) inhibition assay } \\
\text { inVero E6 cells }\end{array}$ & $\mathrm{EC}_{50} 24 \mathrm{nM}^{13}$ & $\begin{array}{l}\text { Vero E6: } \mathrm{CC}_{50}>900 \\
\mathrm{nM}^{13}\end{array}$ \\
\hline Bosutinib (19) & SARS-CoV-2 & $\begin{array}{l}\text { Cytopathic effect (CPE) inhibition assay } \\
\text { in Vero E6 cells }\end{array}$ & $\mathrm{EC}_{50} 20 \mathrm{nM}^{13}$ & $\begin{array}{l}\text { Vero E6: } \mathrm{CC}_{50}>1 \\
\mu \mathrm{M}^{13}\end{array}$ \\
\hline Gilteritinib (20, & SARS-CoV-2 & Cytopathic effect (CPE) inhibition assay & $\mathrm{EC}_{50} 225 \mathrm{nM}^{13}$ & Vero E6: $\mathrm{CC}_{50}>500$ \\
\hline
\end{tabular}




\begin{tabular}{|c|c|c|c|c|}
\hline ASP2215) & & in Vero E6 cells & & $\mathrm{nM}^{13}$ \\
\hline Crizotinib (21) & EV-A71 & $\begin{array}{l}\text { Cytopathic effect (CPE) inhibition assay } \\
\text { in } \mathrm{RD} \text { cells }\end{array}$ & $\begin{array}{l}>50 \% \text { inhibition at } \\
10 \mu \mathrm{M}^{14}\end{array}$ & $\mathrm{CC}_{50}>10 \mu \mathrm{M}^{14}$ \\
\hline \multirow[t]{4}{*}{ Dasatinib (22) } & SARS-CoV, & $\begin{array}{l}\text { Cytopathic effect (CPE) inhibition assay } \\
\text { in Vero E6 cells }\end{array}$ & $\mathrm{EC}_{50} 2.1 \mu \mathrm{M}^{9}$ & \multirow[t]{4}{*}{$\begin{array}{l}\text { Vero E6, Huh 7.5.1: } \\
\mathrm{CC}_{50}>10 \mu \mathrm{M}^{9,15,16}\end{array}$} \\
\hline & MERS-CoV & $\begin{array}{l}\text { Cytopathic effect (CPE) inhibition assay } \\
\text { in Vero E6 cells }\end{array}$ & $\mathrm{EC}_{50} 5.4 \mu \mathrm{M}^{9}$ & \\
\hline & DENV-2 & Focus forming assay in Huh7 cells & $\mathrm{EC}_{90} 4.7 \mu \mathrm{M}^{16}$ & \\
\hline & $\mathrm{HCV}$ & Assay performed in Huh-7.5 cells & $\mathrm{IC}_{50} 0.5 \mu \mathrm{M}^{15}$ & \\
\hline \multirow[t]{6}{*}{ Erlotinib (23) } & $\mathrm{HCV}$ & $\begin{array}{l}\text { Focus forming assay and Luciferase } \\
\text { assay in Huh } 7.5 \text { cells }\end{array}$ & $\mathrm{EC}_{50} 0.6 \mu \mathrm{M}^{15,17-19}$ & $\begin{array}{l}\text { Huh7.5: } \mathrm{CC}_{50}>5 \mu \mathrm{M}^{15} \\
17-19\end{array}$ \\
\hline & DENV1-4 & $\begin{array}{l}\text { Luciferase assay in MDDC, Luciferase } \\
\text { assay and Plaque assay in Huh7/ BHK- } \\
21 \text { cells }\end{array}$ & $\begin{array}{l}\mathrm{EC}_{50} 4 \mu \mathrm{M}^{20} \\
\mathrm{EC}_{50} 1.3-6.5 \mu \mathrm{M}^{18}\end{array}$ & $\begin{array}{l}\text { MDDC: } \mathrm{CC}_{50}>50 \\
\mu \mathrm{M}^{20}, \mathrm{Huh} 7, \mathrm{BHK}-21: \\
\mathrm{CC}_{50}>15 \mu \mathrm{M}^{18}\end{array}$ \\
\hline & ZIKV & Plaque assay in Huh7 cells & $\mathrm{EC}_{50} 6.2 \mu \mathrm{M}^{18}$ & Huh7: $\mathrm{CC}_{50}>30 \mu \mathrm{M}^{18}$ \\
\hline & EBOV & Immunostaining in Huh7/Vero cells & $\mathrm{EC}_{50} 12.9 / 2.8 \mu \mathrm{M}^{18}$ & $\begin{array}{l}\text { Huh7, Vero: } \mathrm{CC}_{50}>14 \\
\mu \mathrm{M}^{18}\end{array}$ \\
\hline & CHIKV & Plaque assay in Vero cells & $\mathrm{EC}_{50} 0.7 \mu \mathrm{M}^{18}$ & Vero: $\mathrm{CC}_{50}>30 \mu \mathrm{M}^{18}$ \\
\hline & JUNV & $\begin{array}{l}\text { Cytopathic effect (CPE) inhibition assay } \\
\text { in Vero cells }\end{array}$ & $\mathrm{EC}_{50} 1.7 \mu \mathrm{M}^{18}$ & Vero: $\mathrm{CC}_{50}>20 \mu \mathrm{M}^{18}$ \\
\hline
\end{tabular}




\begin{tabular}{|c|c|c|c|c|}
\hline & HIV & $\begin{array}{l}\text { Luciferase assay and Plaque assay in } \\
\text { HeLa/ TZM-b1 cells }\end{array}$ & $\mathrm{EC}_{50} 2 \mu \mathrm{M}^{18}$ & $\begin{array}{l}\text { HeLa, TZM-b1: } \mathrm{CC}_{50}> \\
20 \mu \mathrm{M}^{18}\end{array}$ \\
\hline & RSV & Immunoplaque assay in Hep2 cells & $\mathrm{EC}_{50}<0.12 \mu \mathrm{M}^{18}$ & Hep2: $\mathrm{CC}_{50}>30 \mu \mathrm{M}^{18}$ \\
\hline Gefitinib (24) & VACV & $\begin{array}{l}\text { plaque assay in vaccinia virus (VACV)- } \\
\text { infected Hep2 cells }\end{array}$ & $\mathrm{EC}_{50} 4.9 \mu \mathrm{M}^{21}$ & Hep2: $\mathrm{CC}_{50}>100 \mu \mathrm{M}^{21}$ \\
\hline \multirow[t]{7}{*}{$\begin{array}{l}\text { Sorafenib (25), } \\
\text { BAY43-9006 }\end{array}$} & $\mathrm{HCV}$ & Luciferase assay in Huh7.5 cells & $\mathrm{IC}_{50} 7.2 \mu \mathrm{M}^{22}$ & $\begin{array}{l}\text { Huh7.5: } \mathrm{CC}_{50}>20 \\
\mu \mathrm{M}^{22}\end{array}$ \\
\hline & EV71 & $\begin{array}{l}\text { Cytopathic effect (CPE) inhibition assay } \\
\text { in SK-N-SH/RD/Vero cells }\end{array}$ & $\mathrm{IC}_{50} 1.3 / 1.5 / 6.5 \mu \mathrm{M}^{23}$ & $\begin{array}{l}\text { SK-N-SH/RD/Vero: } \\
\mathrm{CC}_{50} 7.9 / 7.0 / 26.3 \mu \mathrm{M}^{23}\end{array}$ \\
\hline & MERS-CoV & Plaque reduction assay in Huh7 cells & $93 \%$ inh. at $10 \mu \mathrm{M}^{24}$ & Huh7: $\mathrm{CC}_{50}>10 \mu \mathrm{M}^{24}$ \\
\hline & RVFV & Plaque reduction assay in vero cells & $\mathrm{EC}_{50} 3.9 \mu \mathrm{M}^{25}$ & Vero: $\mathrm{CC}_{50}>160 \mu \mathrm{M}^{25}$ \\
\hline & $\begin{array}{l}\text { VEEV/EEEV/SINV/C } \\
\text { HIKV }\end{array}$ & Plaque assay in vero cells & $\begin{array}{l}\mathrm{EC}_{50} 6.2 / 6.7 / 1.3 / 0.1 \\
\mu \mathrm{M}^{26}\end{array}$ & Vero: $\mathrm{CC}_{50}>80 \mu \mathrm{M}^{26}$ \\
\hline & RABV & Fluorescent focus assay in N2A cells & $70 \%$ inh. at $5 \mu \mathrm{M}^{27}$ & N2A: $\mathrm{CC}_{50}>50 \mu \mathrm{M}^{27}$ \\
\hline & IAV & $\begin{array}{l}\text { Fluorescent focus assay in cells in A549 } \\
\text { cells }\end{array}$ & $\mathrm{IC}_{50} 0.4 \mu \mathrm{M}^{28}$ & A549: $\mathrm{CC}_{50} 36.2 \mu \mathrm{M}^{28}$ \\
\hline Regorafenib (26) & IAV & $\begin{array}{l}\text { Fluorescent focus assay in cells in A549 } \\
\text { cells }\end{array}$ & $\mathrm{EC}_{50} 0.89 \mu \mathrm{M}^{28}$ & A549: $\mathrm{CC}_{50} 14.1 \mu \mathrm{M}^{28}$ \\
\hline $\begin{array}{l}\text { Midostaurin (27, } \\
\text { PKC-412) }\end{array}$ & HIV-1 & $\begin{array}{l}\text { Cell cytometry assay in primary MDM } \\
\text { cells }\end{array}$ & $\mathrm{EC}_{50} 0.4 \mu \mathrm{M}^{29}$ & $\begin{array}{l}\text { MDM: Nontoxic at } 0.4 \\
\mu \mathrm{M}^{29}\end{array}$ \\
\hline Sunitinib (28) & $\mathrm{HCV}$ & $\begin{array}{l}\text { Focus forming assay and Luciferase } \\
\text { assay in Huh7.5 cells }\end{array}$ & $\mathrm{EC}_{50} 0.4-1.2 \mu \mathrm{M}^{17-19}$ & $\begin{array}{l}\text { Huh7.5: } \mathrm{CC}_{50}>10 \\
\mu \mathrm{M}^{17-19}\end{array}$ \\
\hline
\end{tabular}




\begin{tabular}{|c|c|c|c|c|}
\hline & \begin{tabular}{|l|} 
DENV 1-4 \\
\end{tabular} & $\begin{array}{l}\text { Luciferase assay and Plaque assay in } \\
\text { Huh7/ BHK-21 cells }\end{array}$ & $\mathrm{EC}_{50} 0.2-0.6 \mu \mathrm{M}^{18}$ & $\begin{array}{l}\text { Huh7/ BHK-21: } \mathrm{CC}_{50}> \\
15 \mu \mathrm{M}^{18}\end{array}$ \\
\hline & ZIKV & Plaque assay in Huh7 cells & $\mathrm{EC}_{50} 0.5 \mu \mathrm{M}^{18}$ & Huh7: $\mathrm{CC}_{50} 14.1 \mu \mathrm{M}^{18}$ \\
\hline & EBOV & Immunostaining in Huh7 cells & $\mathrm{EC}_{50} 0.4 \mu \mathrm{M}^{18}$ & Huh7: $\mathrm{CC}_{50}>10 \mu \mathrm{M}^{18}$ \\
\hline & CHIKV & Plaque assay in Vero cells & $\mathrm{EC}_{50} 4.6 \mu \mathrm{M}^{18}$ & Vero: $\mathrm{CC}_{50} 11.9 \mu \mathrm{M}^{18}$ \\
\hline & \begin{tabular}{|l|} 
JUNV \\
\end{tabular} & $\begin{array}{l}\text { Cytopathic effect (CPE) inhibition assay } \\
\text { in Vero cells }\end{array}$ & $\mathrm{EC}_{50} 4.8 \mu \mathrm{M}^{18}$ & Vero: $\mathrm{CC}_{50} 10.4 \mu \mathrm{M}^{18}$ \\
\hline & HIV & $\begin{array}{l}\text { Luciferase assay and Plaque assay in } \\
\text { HeLa/ TZM-b1 cells }\end{array}$ & $\mathrm{EC}_{50} 0.8 \mu \mathrm{M}^{18}$ & $\begin{array}{l}\text { HeLa/ TZM-b1: } \mathrm{CC}_{50}> \\
20 \mu \mathrm{M}^{18}\end{array}$ \\
\hline & RSV & Immunoplaque assay in Hep2 cells & $\mathrm{EC}_{50}<0.12 \mu \mathrm{M}^{18}$ & Hep2: $\mathrm{CC}_{50} 12.5 \mu \mathrm{M}^{18}$ \\
\hline & WNV & Focus forming assay in MEF/Vero cells & $\mathrm{EC}_{50} 0.5 \mu \mathrm{M}^{18}$ & $\begin{array}{l}\text { MEF/Vero: } \mathrm{CC}_{50}>20 \\
\mu \mathrm{M}^{18}\end{array}$ \\
\hline Baricitinib (29) & SARS-CoV-2 & $\begin{array}{l}\text { Viral load measured by qPCR in primary } \\
\text { human liver spheroids }\end{array}$ & $\begin{array}{l}30-40 \% \text { red. At } 400 \\
\text { and } 800 \mathrm{nM}^{30}\end{array}$ & $\begin{array}{l}\text { human liver spheroids: } \\
\mathrm{CC}_{50}>5 \mu \mathrm{M}^{30}\end{array}$ \\
\hline Ruxolitinib (30) & HIV-1 & $\begin{array}{l}\text { Assay performed in human PBMC } \\
\text { (Primary human peripheral blood } \\
\text { mononuclear) cells/Primary human } \\
\text { macrophages }\end{array}$ & $\mathrm{EC}_{50} 0.1 / 0.3 \mu \mathrm{M}^{31,32}$ & $\begin{array}{l}\text { hPBMC/primary } \\
\text { human macrophages: } \\
\mathrm{CC}_{50}>100 \mu \mathrm{M}^{31,32}\end{array}$ \\
\hline & HIV-2 & Assay performed in human PBM cells & $\mathrm{EC}_{50} 0.02 \mu \mathrm{M}^{31,32}$ & $\begin{array}{l}\text { hPBMC: } \mathrm{CC}_{50}>100 \\
\mu \mathrm{M}^{31,32}\end{array}$ \\
\hline
\end{tabular}




\begin{tabular}{|c|c|c|c|c|c|}
\hline Tofacitinib (31) & HIV-1 & $\begin{array}{l}\text { Assay performed in human PBM } \\
\text { (Primary human peripheral blood } \\
\text { mononuclear) cells/Primary human } \\
\text { macrophages }\end{array}$ & $\mathrm{EC}_{50} 0.8 / 0.2 \mu \mathrm{M}^{31}$ & $\begin{array}{l}\text { PBM/primary human } \\
\text { macrophages: } \mathrm{CC}_{50} \\
62 />100 \mu \mathrm{M}^{31}\end{array}$ & \\
\hline & HIV-2 & Assay performed in human PBM cells & $\mathrm{EC}_{50} 0.07 \mu \mathrm{M}^{31}$ & PBM: $\mathrm{CC}_{50}>100 \mu \mathrm{M}^{31}$ & \\
\hline Leflunomide (32) & $\mathrm{CMV}$ & Assay performed in HFF cells & $\mathrm{IC}_{50} 40-60 \mu \mathrm{M}^{33}$ & & $\begin{array}{l}\text { HSG: } \mathrm{CC}_{50} 20.8 \\
\mu \mathrm{M}^{34}\end{array}$ \\
\hline \multirow[t]{4}{*}{ A771726 (33) } & IAV H5N1 & $\begin{array}{l}\text { Viral load measured in MDCK/A549 } \\
\text { cells }\end{array}$ & $\begin{array}{l}80 / 20 \% \text { reduction at } \\
50 \mu \mathrm{M}^{35}\end{array}$ & $\begin{array}{l}\text { CEF/MDCK/A549: } \\
\mathrm{CC}_{50}>100 \mu \mathrm{M}^{35}\end{array}$ & \\
\hline & IAV H1N1 & $\begin{array}{l}\text { Viral load measured in } \\
\mathrm{CEF} / \mathrm{MDCK} / \mathrm{A} 549 \text { cells }\end{array}$ & $\begin{array}{l}95 / 50 / 50 \% \\
\text { reduction at } 50 \\
\mu \mathrm{M}^{35}\end{array}$ & $\begin{array}{l}\text { CEF/MDCK/A549: } \\
\mathrm{CC}_{50}>100 \mu \mathrm{M}^{35}\end{array}$ & \\
\hline & IAV H9N2 & $\begin{array}{l}\text { Viral load measured in } \\
\text { CEF/MDCK/A549 cells }\end{array}$ & $\begin{array}{l}10 / 65 / 95 \% \\
\text { reduction at } 50 \\
\mu \mathrm{M}^{35}\end{array}$ & $\begin{array}{l}\text { CEF/MDCK/A549: } \\
\mathrm{CC}_{50}>100 \mu \mathrm{M}^{35}\end{array}$ & \\
\hline & JUNV & $\begin{array}{l}\text { virus yield inhibition assay in vero/A549 } \\
\text { cells }\end{array}$ & $\mathrm{EC}_{50} 16.6-45.5 \mu \mathrm{M}^{36}$ & $\begin{array}{l}\text { Vero/A549: } \mathrm{CC}_{50} \\
223.1 / 259.3 \mu \mathrm{M}^{36}\end{array}$ & \\
\hline Zanubrutinib (34) & SARS-CoV 2 & \multicolumn{3}{|l|}{ Information not available } & $\begin{array}{l}\text { MCL: } \mathrm{IC}_{50}>1.4 \\
\mu \mathrm{M}^{37}\end{array}$ \\
\hline Ibtrutinib (35) & SARS-CoV 2 & \multicolumn{3}{|l|}{ Information not available } & $\begin{array}{l}\text { DU145, PC3: } \\
\mathrm{CC}_{50}>20 \mu \mathrm{M}^{38}\end{array}$ \\
\hline Palbociclib (36) & HIV-1 & Flow cytometry assay in MDM cells & $\begin{array}{l}\mathrm{EC}_{50} 16-120 \\
\mathrm{nM}^{39,40}\end{array}$ & $\begin{array}{l}\text { MDM: } \mathrm{CC}_{50} 21.4 \\
\mu \mathrm{M}^{39,40}\end{array}$ & \\
\hline
\end{tabular}




\begin{tabular}{|c|c|c|c|c|c|}
\hline & HSV-1 & Flow cytometry assay in MDM cells & $\mathrm{EC}_{50} 0.02 \mu \mathrm{M}^{40}$ & MDM: $\mathrm{CC}_{50}>4 \mu \mathrm{M}^{40}$ & \\
\hline Everolimus (37) & MERS-CoV & Plaque reduction assay in Huh7 cells & $\begin{array}{l}>50 \% \text { inhibition } \\
\text { @ } 10 \mu \mathrm{M}^{24}\end{array}$ & Huh7: $\mathrm{CC}_{50}>10 \mu \mathrm{M}^{24}$ & \\
\hline Trametinib (38) & H1N1pdm09 IAV & Plaque reduction assay in A549 cells & $\mathrm{EC}_{50} 16 \mathrm{nM}^{4 \Gamma}$ & $\begin{array}{l}\text { A549/MDCKII/HBEp } \\
\text { C: } \mathrm{CC}_{50}>20 \mu \mathrm{M}^{41}\end{array}$ & \\
\hline $\begin{array}{l}\text { Selumetinib (AZD- } \\
6244 ; 39)\end{array}$ & H1N1pdm09 IAV & Plaque reduction assay in A549 cells & $\mathrm{EC}_{50} 0.7 \mu \mathrm{M}^{42}$ & A549: $\mathrm{CC}_{50}>100 \mu \mathrm{M}^{42}$ & \\
\hline BIBX 1382 (40) & LASV/EBOV/MARV & Viral titer reduction assay in Vero E6 cells & $\begin{array}{l}\mathrm{EC}_{50} 3.2 / 1.1 / 1.8 \\
\mu \mathrm{M}^{43}\end{array}$ & $\begin{array}{l}\text { Vero: } \mathrm{CC}_{50}>15.3 / 19.8 / \\
29.1 \mu \mathrm{M}^{43}\end{array}$ & \\
\hline $\begin{array}{l}\text { Canertinib (41, CI } \\
\text { 1033) }\end{array}$ & Variola virus & No. of plaques measured in BCS-40 cells & $\begin{array}{l}\text { no. of plaques } \\
\text { reduced to } 30 \% \\
\text { @ } 1 \mu \mathrm{M}^{44}\end{array}$ & $\begin{array}{l}\text { BSC-40/Vero: } \mathrm{CC}_{50} \\
>10 \mu \mathrm{M}^{44}\end{array}$ & \\
\hline $\begin{array}{l}\text { Bemcentinib (42, } \\
\text { R428, BGB324) }\end{array}$ & ZIKV & Plaque assay in SerC cells & $\begin{array}{l}75 \% \text { inh. at } 1 \\
\mu \mathrm{M}^{45}\end{array}$ & SerC: $\mathrm{CC}_{50}>10 \mu \mathrm{M}^{45}$ & \\
\hline \multirow[t]{2}{*}{$\begin{array}{l}\text { Saracatinib (43, } \\
\text { AZD0530) }\end{array}$} & $\begin{array}{l}\text { MERS-CoV/hCoV- } \\
\text { 229E/hCoV-OC43/ } \\
\text { FIPV }\end{array}$ & $\begin{array}{l}\text { Cytopathic effect (CPE) inhibition assay in } \\
\text { Huh } 7 \text { cells }\end{array}$ & $\begin{array}{l}\mathrm{EC}_{50} \\
2.9 / 2.4 / 5.1 / 7 \\
\mu \mathrm{M}^{46}\end{array}$ & Huh 7: $\mathrm{CC}_{50}>20 \mu \mathrm{M}^{46}$ & \\
\hline & DENV 2 & Focus-forming assay (FFA) in Huh 7 cells & $\mathrm{EC}_{50} 12.2 \mu \mathrm{M}^{16}$ & Huh 7: $\mathrm{CC}_{50} 74 \mu \mathrm{M}^{16}$ & \\
\hline Pacritinib (44) & SARS-CoV 2 & \multicolumn{3}{|l|}{ Information not available } & $\begin{array}{l}\text { LN18: } \mathrm{CC}_{50}>1 \\
\mu \mathrm{M}^{47}\end{array}$ \\
\hline AT9283 (45) & HSV-1 & Assay performed in Vero cells & $\begin{array}{l}80 \% \text { inhibition @ } \\
10 \mu \mathrm{M}^{48}\end{array}$ & Vero: $\mathrm{CC}_{50}>20 \mu \mathrm{M}^{48}$ & \\
\hline
\end{tabular}




\begin{tabular}{|c|c|c|c|c|c|}
\hline $\begin{array}{l}\text { Filgotinib (46, } \\
\text { GLPG0634) }\end{array}$ & HIV-1 & $\begin{array}{l}\text { dsGFP expression levels checked in } \\
\text { 1D7(SPECC1)/1G2(RAP1B)/8B10(VAV1) } \\
\text { cells }\end{array}$ & $\begin{array}{l}\mathrm{EC}_{50} 3.1 / 6.8 / 11.2 \\
\mu \mathrm{M}^{49}\end{array}$ & $\begin{array}{l}\text { Jurkat 6C6-du: } \mathrm{IC}_{50} \\
>10 \mu \mathrm{M}^{49}\end{array}$ & \\
\hline $\begin{array}{l}\text { Lestaurtinib (47, } \\
\text { CEP-701, KT- } \\
\text { 5555) }\end{array}$ & SARS-CoV 2 & $\begin{array}{l}\text { Predicted for SARS-CoV-2 } \\
\text { using RNA sequencing data }\end{array}$ & & & $\begin{array}{l}\text { BFTC905: } \text { CC }_{50} \\
>3 \mu \mathrm{M}^{50}\end{array}$ \\
\hline \multirow[t]{5}{*}{$\begin{array}{l}\text { Seliciclib }(48, \\
\text { roscovitine) }\end{array}$} & ZIKV & Focus forming assay in Vero cells & $\mathrm{IC}_{50} 24 \mathrm{nM}^{5}$ & $\begin{array}{l}\text { Human iPSC-derived } \\
\text { astrocytes (BJ line): } \\
\mathrm{CC}_{50}>10 \mu \mathrm{M}^{5}\end{array}$ & \\
\hline & HIV-1 & $\begin{array}{l}\text { Titration } \\
\text { curve performed in OM10.1 and U1 cells }\end{array}$ & $\begin{array}{l}\mathrm{IC}_{50} 0.36 / 1.8 \\
\mu \mathrm{M}^{51}\end{array}$ & $\begin{array}{l}\text { CEM/THP-1/PBMC: } \\
\mathrm{CC}_{50} 28 / 35 / 22 \mu \mathrm{M}^{51}\end{array}$ & \\
\hline & $\mathrm{VZV}$ & Plaque reduction assay in MeWo cells & $\mathrm{EC}_{50} 12 \mu \mathrm{M}^{52}$ & MeWo: $\mathrm{CC}_{50}>25 \mu \mathrm{M}^{52}$ & \\
\hline & $\begin{array}{l}\text { IAV } \\
\text { A/WSN/1933(H1N1), } \\
\text { A/Aichi/2/68(H3N2), } \\
\text { A/FM1/47 (H1N1) }\end{array}$ & $\begin{array}{l}\text { Cytopathic effect (CPE) inhibition assay in } \\
\text { MDCK cells }\end{array}$ & $\begin{array}{l}\mathrm{IC}_{50} 3.3 / 7.0 / 5.9 \\
\mu \mathrm{M}^{53}\end{array}$ & $\begin{array}{l}\text { MDCK: } \mathrm{CC}_{50}>200 \\
\mu \mathrm{M}^{53}\end{array}$ & \\
\hline & HCMV & $\begin{array}{l}\text { Abundance of DNA determined by slot blot } \\
\text { hybridization using LU cells }\end{array}$ & $\begin{array}{l}50 \% \text { inhibition @ } \\
1 \mu \mathrm{M}^{54}\end{array}$ & LU: $\mathrm{CC}_{50}>15 \mu \mathrm{M}^{54}$ & \\
\hline Olomoucine (49) & HCMV & $\begin{array}{l}\text { Abundance of DNA determined by slot blot } \\
\text { hybridization using LU cells }\end{array}$ & $\begin{array}{l}50 \% \text { inhibition @ } \\
10 \mu \mathrm{M}^{54}\end{array}$ & LU: $\mathrm{CC}_{50}>15 \mu \mathrm{M}^{54}$ & \\
\hline \multirow[t]{2}{*}{ FIT-039 (50) } & HSV-1 & Real-time PCR performed using HeLa cells & $\mathrm{IC}_{50} 0.69 \mu \mathrm{M}^{55}$ & HeLa: $\mathrm{CC}_{50}>10 \mu \mathrm{M}^{55}$ & \\
\hline & HBV & qPCR performed using HepG2/NTCP cells & $\mathrm{IC}_{50} 0.33 \mu \mathrm{M}^{56}$ & HepG2/NTCP: $\mathrm{CC}_{50}$ & \\
\hline
\end{tabular}




\begin{tabular}{|c|c|c|c|c|c|}
\hline & & & & $>50 \mu \mathrm{M}^{56}$ & \\
\hline PHA-767491 (51) & $\begin{array}{l}\text { HSV-1 induced } \\
\text { necrosis }\end{array}$ & $\begin{array}{l}\text { fluorescence intensity measured in L929 } \\
\text { cells }\end{array}$ & $\mathrm{IC}_{50} 1.86 \mu \mathrm{M}^{57}$ & & $\begin{array}{l}\text { 24ST1NLESG: } \\
\mathrm{CC}_{50} 1 \mu \mathrm{M}^{58}\end{array}$ \\
\hline PD-0325901 (52) & H1N1pdm09 IAV & Plaque reduction assay in A549 cells & $\mathrm{EC}_{50} 5 \mathrm{nM}^{42}$ & A549: $\mathrm{CC}_{50}>100 \mu \mathrm{M}^{42}$ & \\
\hline AZD-8330 (53) & H1N1pdm09 IAV & Plaque reduction assay in A549 cells & $\mathrm{IC}_{50} 40 \mathrm{nM}^{42}$ & A549: $\mathrm{CC}_{50}>100 \mu \mathrm{M}^{42}$ & \\
\hline $\begin{array}{l}\text { Refametinib (54, } \\
\text { RDEA-119) }\end{array}$ & H1N1pdm09 IAV & Plaque reduction assay in A549 cells & $\mathrm{IC}_{50} 60 \mathrm{nM}^{42}$ & A549: $\mathrm{CC}_{50}>100 \mu \mathrm{M}^{42}$ & \\
\hline PD184352 (55) & IAV HINI & Standard Plaque assay in A549 cells & $\begin{array}{l}\mathrm{EC}_{50} \\
0.026 \mu \mathrm{M}^{59}\end{array}$ & A549: $\mathrm{CC}_{50}>312 \mu \mathrm{M}^{59}$ & \\
\hline MK2206 (57) & H1N1 IAV & $\begin{array}{l}\text { Plaque forming units (PFU) in NCI-H1666 } \\
\text { cells }\end{array}$ & $\mathrm{EC}_{50} 790 \mathrm{nM}^{60}$ & $\begin{array}{l}\text { NCI-H1666: } \mathrm{CC}_{50} 58.5 \\
\mu \mathrm{M}^{60}\end{array}$ & \\
\hline CX-6258 (58) & EV-A71 & $\begin{array}{l}\text { mRNA level was determined by qRT-PCR } \\
\text { using } 293 \mathrm{~T}, \mathrm{RD} \text {, HeLa cells }\end{array}$ & $\begin{array}{l}70-80 \% \text { reduction } \\
\text { in viral mRNA@ } \\
2 \mu \mathrm{M}^{61}\end{array}$ & $\begin{array}{l}\text { 293T, RD, HeLa: } \mathrm{CC}_{50} \\
>8 \mu \mathrm{M}^{61}\end{array}$ & \\
\hline BI 2536 (59) & IAV & Luciferase activity assay in MDCK cells & $\mathrm{IC}_{50} 0.08 \mu \mathrm{M}^{62}$ & $\begin{array}{l}\text { MDCK: } \mathrm{CC}_{50} 1.86 \\
\mu \mathrm{M}^{62}\end{array}$ & \\
\hline $\begin{array}{l}\text { BEZ-235 (60, } \\
\text { Dactolisib) }\end{array}$ & LCMV & $\begin{array}{l}\text { Virus titers were determined using an } \\
\text { immune focus forming } \\
\text { assay in } 293 \mathrm{~T} \text { cells }\end{array}$ & $\begin{array}{l}2-2.5 \log \\
\text { reduction in virus } \\
\text { progeny @ 0.5-5 } \\
\mu \mathrm{M}^{63}\end{array}$ & 293T: $\mathrm{CC}_{50}>5 \mu \mathrm{M}^{63}$ & \\
\hline $\begin{array}{l}\text { Opaganib, }(61, \\
\text { ABC294640) }\end{array}$ & IAV & Plaque assay in A549 cells & $\mathrm{IC}_{50} 1.78 \mu \mathrm{M}^{64}$ & & $\begin{array}{l}\mathrm{BxPC} 3 / \mathrm{MiaPaCa} \\
-2 / \mathrm{Panc}-1: \mathrm{CC}_{50}\end{array}$ \\
\hline
\end{tabular}




\begin{tabular}{|c|c|c|c|c|c|}
\hline & & & & & $\begin{array}{l}28.5 / 35.2 / 23.2 \mu \\
\mathrm{M}^{65}\end{array}$ \\
\hline Vacuolin-1 (62) & ZEBOV & $\begin{array}{l}\text { Fluorescence } \\
\text { microscopy in SVG-A cells }\end{array}$ & $\begin{array}{l}\text { Blocked the entry } \\
\text { of ZEBOV via } \\
\text { inhibition of } \\
\text { PIKfyve }^{66}\end{array}$ & & $\begin{array}{l}\text { PC3,MCF-7: } \\
\mathrm{CC}_{50}>10 \mu \mathrm{M}^{67}\end{array}$ \\
\hline \multirow[t]{3}{*}{$\begin{array}{l}\text { OSU-03012 (63, } \\
\text { AR-12) }\end{array}$} & ZIKV & $\begin{array}{l}\text { Viral load reduction assay in } \mathrm{U} 251 \text { and } \\
\text { SF268 cells }\end{array}$ & $\begin{array}{l}\mathrm{IC}_{50} 0.84 / 1.18 \\
\mu \mathrm{M}^{68}\end{array}$ & $\begin{array}{l}\text { U251, SF268: } \mathrm{CC}_{50}>6 \\
\mu \mathrm{M}^{68}\end{array}$ & \\
\hline & LASV/EBOV & Viral titer reduction assay in Vero E6 cells & $\begin{array}{l}\mathrm{EC}_{50} 257 / 172 \\
\mathrm{nM}^{43}\end{array}$ & $\begin{array}{l}\text { Vero E6: } \mathrm{CC}_{50}>5.7 \\
\mu \mathrm{M}^{43}\end{array}$ & \\
\hline & $\begin{array}{l}\text { NiV-Luc, EBOV-GFP, } \\
\text { MARV-GFP: }\end{array}$ & Assay performed in Huh 7 cells & $\mathrm{EC}_{50} 0.3 \mu \mathrm{M}^{43}$ & Huh-7: $\mathrm{CC}_{50}>10 \mu \mathrm{M}^{43}$ & \\
\hline \multirow[t]{3}{*}{ Genistein (64) } & $\mathrm{HIV}$ & Assay performed in primary macrophages & $\begin{array}{l}>95 \% \text { inhibition } \\
\text { of virus } \\
\text { replication and } \\
\text { spread @ } 5 \\
\text { and } 10 \mu \mathrm{g} / \mathrm{ml}^{69}\end{array}$ & $\begin{array}{l}\text { Primary macrophages: } \\
\mathrm{CC}_{50}>10 \mu \mathrm{g} / \mathrm{mL}^{69}\end{array}$ & \\
\hline & HSV-1 & Plaque-formation assay on Vero cells & $\begin{array}{l}89 \% \text { reduction in } \\
\text { virus yield @ } \\
\text { concentration of } \\
50 \mu \mathrm{M}^{70}\end{array}$ & Vero: $\mathrm{CC}_{50}>50 \mu \mathrm{M}^{70}$ & \\
\hline & $\mathrm{PICV}$ & Plaque-formation assay on Vero cells & $\begin{array}{l}90 \% \text { red. in viral } \\
\text { titers @ } 100 \mu \mathrm{M}^{71}\end{array}$ & Vero: $\mathrm{CC}_{50}>100 \mu \mathrm{M}^{71}$ & \\
\hline
\end{tabular}

Page S13 


\begin{tabular}{|c|c|c|c|c|c|}
\hline & HBV & $\begin{array}{l}\text { Plaque reduction assay in HFF and RMF } \\
\text { cells }\end{array}$ & $\mathrm{IC}_{90} 33 / 46 \mu \mathrm{M}^{72}$ & $\begin{array}{l}\text { HFF,RMF: } \mathrm{CC}_{50}>100 \\
\mu \mathrm{M}^{72}\end{array}$ & \\
\hline GNF-2 (65) & DENV2 & Plaque-formation assay on BHK21 cells & $\mathrm{IC}_{90} 15 \mu \mathrm{M}^{73}$ & & $\begin{array}{l}\text { Microglia: } \mathrm{CC}_{50} \\
20 \mu \mathrm{M}^{74}\end{array}$ \\
\hline PD $166326(66)$ & Vaccinia virus & $\begin{array}{l}\text { Standard Plaque assay in } 3 \mathrm{~T} 3 \text { or BSC-40 } \\
\text { cells }\end{array}$ & $\begin{array}{l}90 \% \text { red. in } \\
\text { infected cells @ } \\
10 \mu \mathrm{M}^{75}\end{array}$ & & $\begin{array}{l}\text { Macrophages: } \\
\mathrm{CC}_{50} 5 \mu \mathrm{M}^{76}\end{array}$ \\
\hline WAY-600 (67) & ZIKV & Assay performed in hJeg-3 cells & $\mathrm{IC}_{50} 2.3 \mu \mathrm{M}^{77}$ & HJeg-3: $\mathrm{CC}_{50}>10 \mu \mathrm{M}^{77}$ & \\
\hline \multirow[t]{2}{*}{ Hesperadin (68) } & $\begin{array}{l}\text { IAV } \\
\text { A/California/07/2009 } \\
\text { H1N1 }\end{array}$ & Standard Plaque assay in MDCK cells & $\mathrm{EC}_{50} 0.28 \mu \mathrm{M}^{78}$ & $\begin{array}{l}\text { MDCK: } \mathrm{CC}_{50} 21.3 \\
\mu \mathrm{M}^{78}\end{array}$ & \\
\hline & $\begin{array}{l}\text { A/California/02/2014 } \\
\text { (H3N2) }\end{array}$ & Standard Plaque assay in MDCK cells & $\mathrm{EC}_{50} 1.80 \mu \mathrm{M}^{78}$ & & \\
\hline \multirow[t]{2}{*}{$\begin{array}{l}\text { Tyrphostin A9 } \\
\text { (69) }\end{array}$} & $\begin{array}{l}\text { TGEV, MHV, PEDV, } \\
\text { FIPV }\end{array}$ & $\begin{array}{l}\text { Standard Plaque assay in PK-15 and ST } \\
\text { cells }\end{array}$ & $\begin{array}{l}2.3-4.7 \log \\
\text { reduction in } \\
\text { virus progeny @ } \\
4 \mu \mathrm{M}^{79}\end{array}$ & PK-15: $\mathrm{CC}_{50}>6 \mu \mathrm{M}^{79}$ & \\
\hline & IAV & Standard Plaque assay in A549 cells & $\begin{array}{l}\text { Virus yield } \\
\text { red by } 2 \log @ 10 \\
\mu \mathrm{M}^{80}\end{array}$ & A549: $\mathrm{CC}_{50}>3 \mu \mathrm{M}^{80}$ & \\
\hline
\end{tabular}




\begin{tabular}{|c|c|c|c|c|c|}
\hline AG879 (70) & IAV & Standard Plaque assay in A549 cells & $\begin{array}{l}\text { Virus yield } \\
\text { red by } 2 \log @ 10 \\
\mu \mathrm{M}^{80}\end{array}$ & A549: $\mathrm{CC}_{50}>81 \mu \mathrm{M}^{80}$ & \\
\hline WV970 (71) & $\begin{array}{l}\text { H1N1/H3N2/ H5N1/ } \\
\text { H7N9 }\end{array}$ & Standard Plaque assay in MDCK cells & $\begin{array}{l}\mathrm{IC}_{50} \\
15 / 24 / 240 / 230 \mathrm{nM} \\
81\end{array}$ & MDCK: $\mathrm{CC}_{50} 3.8 \mu \mathrm{M}^{81}$ & \\
\hline RO0504985 (72) & HCMV & Viral yield reduction assay in HFF cells & $\mathrm{EC}_{50} 0.01 \mu \mathrm{M}^{82}$ & HFF: $\mathrm{CC}_{50} 10 \mu \mathrm{M}^{82}$ & \\
\hline \multirow[t]{2}{*}{ BX795 (73) } & HSV-1 & $\begin{array}{l}\text { Standard Plaque assay in HCE, HEK, } \\
\text { HeLa cells }\end{array}$ & $\mathrm{EC}_{50} 10 \mu \mathrm{M}^{83}$ & $\begin{array}{l}\text { HCE, HEK, HeLa: } \\
\mathrm{CC}_{50} 51 / 76.5 / 46.3 \\
\mu \mathrm{M}^{83}\end{array}$ & \\
\hline & HSV-2 & Standard Plaque assay in VK2 cells & $\begin{array}{l}>90 \% \text { reduction } \\
\text { in number of PFU } \\
\text { @ } 10 \mu \mathrm{M}^{84}\end{array}$ & VK2: $\mathrm{CC}_{50}>80 \mu \mathrm{M}^{84}$ & \\
\hline Y15 (74) & IAV & $\begin{array}{l}\text { Viral load determined } \\
\text { by TCID50 method }\end{array}$ & $\begin{array}{l}59 \% \text { reduction @ } \\
5 \mathrm{mg} / \mathrm{kg}^{85}\end{array}$ & $\begin{array}{l}\text { Week old female } \\
\text { DBA } / 2 \mathrm{~J} \text { mice: } \mathrm{CC}_{50}>5 \\
\mathrm{mg} / \mathrm{kg}^{85}\end{array}$ & $\begin{array}{l}\mathrm{CC}_{50}:>1 \mu \mathrm{M} \\
(\mathrm{H} 1650, \mathrm{H} 358, \\
\mathrm{A} 549)^{86}\end{array}$ \\
\hline RGB-286147 (75) & ZIKV & Focus forming assay in Vero cells & $\mathrm{IC}_{50} 27 \mathrm{nM}^{5}$ & & $\begin{array}{l}\text { HCT116: } \mathrm{IC}_{50} 40 \\
\mathrm{nM}^{87}\end{array}$ \\
\hline $\begin{array}{l}\text { Alsterpaullone } \\
\text { (76) }\end{array}$ & HIV-1 & Luciferase assay in TZM-bl cells & $\mathrm{IC}_{50} 150 \mathrm{nM}^{88}$ & $\begin{array}{l}\text { CEM, Jurkat, U937: } \\
\mathrm{CC}_{50}>1 \mu \mathrm{M}^{88}\end{array}$ & \\
\hline Purvalanol A (77) & HIV-1 & Flow cytometry assay in MDM cells & $\mathrm{EC}_{50} 2.21 \mu \mathrm{M}^{39}$ & MDM: $\mathrm{CC}_{50} 18.7 \mu \mathrm{M}^{39}$ & \\
\hline
\end{tabular}




\begin{tabular}{|c|c|c|c|c|}
\hline & VZV & $\begin{array}{l}\text { Quantitation of viral genomes using Real } \\
\text { Time PCR in MeWo cells }\end{array}$ & $\mathrm{EC}_{50} 1-2 \mu \mathrm{M}^{89}$ & MeWo: $\mathrm{CC}_{50}>10 \mu \mathrm{M}^{89}$ \\
\hline \multirow[t]{11}{*}{ LDC4297 (78) } & HCMV & GFP-based reporter assay in HFF cells & $\mathrm{EC}_{50} 20 \mathrm{nM}^{90}$ & HFF: $\mathrm{CC}_{50} 5.22 \mu \mathrm{M}^{90}$ \\
\hline & $\begin{array}{l}\text { Influenza A virus } \\
\text { (A/WSN/33) }\end{array}$ & $\begin{array}{l}\text { Polymerase activity-based reporter assay in } \\
293 \mathrm{~T} \text { cells }\end{array}$ & $\mathrm{EC}_{50} 0.99 \mu \mathrm{M}^{90}$ & 293T: $\mathrm{CC}_{50} 3.25 \mu \mathrm{M}^{90}$ \\
\hline & HIV-1 (NL4-3) & $\begin{array}{l}\text { SEAP-based reporter assay in CEMx174 } \\
\text { cells }\end{array}$ & $\mathrm{EC}_{50} 1.0 \mu \mathrm{M}^{90}$ & $\begin{array}{l}\text { CEMx174: } \mathrm{CC}_{50} 17.4 \\
\mu \mathrm{M}^{90}\end{array}$ \\
\hline & Vaccinia virus (IHD-5) & Plaque reduction assay in HFF cells & $\mathrm{EC}_{50} 0.77 \mu \mathrm{M}^{90}$ & HFF: $\mathrm{CC}_{50} 5.2 \mu \mathrm{M}^{90}$ \\
\hline & HAdV-2 (type 2) & Plaque reduction assay in A549 cells & $\mathrm{EC}_{50} 0.25 \mu \mathrm{M}^{90}$ & A549: $\mathrm{CC}_{50} 5.6 \mu \mathrm{M}^{90}$ \\
\hline & EBV (B95-8) & Plaque reduction assay in $293 \mathrm{~T}$ cells & $\mathrm{EC}_{50} 1.2 \mu \mathrm{M}^{90}$ & 293T: $\mathrm{CC}_{50} 3.52 \mu \mathrm{M}^{90}$ \\
\hline & VZV (Oka) & Plaque reduction assay in HFF cells & $\mathrm{EC}_{50} 0.06 \mu \mathrm{M}^{90}$ & HFF: $\mathrm{CC}_{50} 5.22 \mu \mathrm{M}^{90}$ \\
\hline & $\begin{array}{l}\text { HSV-1 (166v VP22- } \\
\text { GFP) }\end{array}$ & Plaque reduction assay in Vero cells & $\mathrm{EC}_{50} 0.02 \mu \mathrm{M}^{90}$ & Vero: $\mathrm{CC}_{50} 3.0 \mu \mathrm{M}^{90}$ \\
\hline & HSV-2 (01-6332) & Plaque reduction assay in Vero cells & $\mathrm{EC}_{50} 0.27 \mu \mathrm{M}^{90}$ & Vero: $\mathrm{CC}_{50} 3.0 \mu \mathrm{M}^{90}$ \\
\hline & MCMV (Smith) & Plaque reduction assay in MEF cells & $\mathrm{EC}_{50} 0.07 \mu \mathrm{M}^{90}$ & MEF: $\mathrm{CC}_{50} 2.85 \mu \mathrm{M}^{90}$ \\
\hline & GPCMV (v403-GFP) & GFP-based reporter assay in GPEF cells & $\mathrm{EC}_{50} 0.05 \mu \mathrm{M}^{90}$ & GPEF: $\mathrm{CC}_{50} 3.59 \mu \mathrm{M}^{90}$ \\
\hline \multirow[t]{2}{*}{ U0126 (79) } & BDV & $\begin{array}{l}\text { standard virus titration assay in OL and } \\
\text { CRL } 1405 \text { cells }\end{array}$ & $\begin{array}{l}99.5 \% \text { reduction } \\
\text { in the virus titer } \\
\text { @ } 25 \mu \mathrm{M}^{91}\end{array}$ & $\begin{array}{l}\text { CRL, OL: } \mathrm{CC}_{50}>50 \\
\mu \mathrm{M}^{91}\end{array}$ \\
\hline & IAV & Standard Plaque assay in MDCK cells & $\begin{array}{l}80 \% \text { reduction in } \\
\text { number of } \\
\text { infectious particle }\end{array}$ & $\begin{array}{l}\text { MDCK: } \mathrm{CC}_{50}>50 \\
\mu \mathrm{M}^{92}\end{array}$ \\
\hline
\end{tabular}

Page S16 


\begin{tabular}{|c|c|c|c|c|}
\hline & & & @ $50 \mu \mathrm{M}^{92}$ & \\
\hline & IBV & Standard Plaque assay in MDCK cells & $\begin{array}{l}90 \% \text { reduction in } \\
\text { number of PFU } \\
\text { @ } 60 \mu \mathrm{M}^{93}\end{array}$ & $\begin{array}{l}\text { MDCK: } \mathrm{CC}_{50}>60 \\
\mu \mathrm{M}^{93}\end{array}$ \\
\hline & $\begin{array}{l}\text { RB1 H1N1/ } \\
\text { MB1 H5N1/ } \\
\text { GSB H5N1/ } \\
\text { FPV H7N7 }\end{array}$ & Avicel plaque assay in A549 cells & $\begin{array}{l}\mathrm{EC}_{50} 1.21 / 4.43 / \\
36.6 / 82.7 \mu \mathrm{M}^{94}\end{array}$ & A549: $\mathrm{CC}_{50} 6.5 \mathrm{mM}^{94}$ \\
\hline & $\begin{array}{l}\text { RB1 H1N1/ } \\
\text { MB1 H5N1/ } \\
\text { GSB H5N1/ } \\
\text { FPV H7N7 }\end{array}$ & Avicel plaque assay in MDCK II cells & $\begin{array}{l}\mathrm{EC}_{50} 74.6 / 19.1 / \\
141.3 / 22.7 \mu \mathrm{M}^{94}\end{array}$ & $\begin{array}{l}\text { MDCKII: } \mathrm{CC}_{50} 97.7 \\
\mathrm{mM}^{94}\end{array}$ \\
\hline & JUNV & Standard Plaque assay in U937 cells & $\begin{array}{l}>70 \% \text { reduction } \\
\text { in titers @ } 2 \mu \mathrm{M}^{95}\end{array}$ & \\
\hline & YFV & $\begin{array}{l}\text { Viral yield }(\mathrm{PFU} / \mathrm{mL}) \text { measured in Vero } \\
\text { cells }\end{array}$ & $\begin{array}{l}90 \% \text { reduction in } \\
\text { number of PFU } \\
\text { @ } 40 \mu \mathrm{M}^{96}\end{array}$ & Vero: $\mathrm{CC}_{50}>40 \mu \mathrm{M}^{96}$ \\
\hline & DENV-2/-3 & $\begin{array}{l}\text { Viral yield }(\mathrm{PFU} / \mathrm{mL}) \text { measured in BHK-21 } \\
\text { cells }\end{array}$ & $\begin{array}{l}>80 \% \text { reduction } \\
\text { in number of PFU } \\
\text { @ } 15 \mu \mathrm{M}^{96}\end{array}$ & \\
\hline $\begin{array}{l}\text { Ginsenoside Rg3 } \\
\text { (80) }\end{array}$ & MHV-68 & Plaque reduction assay in NIH3T3cells & $\mathrm{IC}_{50} 10.8 \mu \mathrm{M}^{97}$ & $\begin{array}{l}\text { NIH3T3: } \mathrm{CC}_{50}>50 \\
\mu \mathrm{M}^{97}\end{array}$ \\
\hline
\end{tabular}

Page S17 


\begin{tabular}{|c|c|c|c|c|c|}
\hline SB203580 (81) & HCoV-229E & Real-time PCR using L132 cells & $\begin{array}{l}>65 \% \text { reduction } \\
\text { in RNA @ } \\
10 \mu \mathrm{M}^{98}\end{array}$ & L132: $\mathrm{CC}_{50}>10 \mu \mathrm{M}^{98}$ & \\
\hline $\begin{array}{l}\text { Bisindolylmaleimi } \\
\text { de }(82)\end{array}$ & IAV WSN & Plaque assay in Mv-1 cells & $\begin{array}{l}1 \log \text { inh. at } 5-10 \\
\mu \mathrm{M}^{99}\end{array}$ & & $\begin{array}{l}\text { HL- } \\
60, \mathrm{MCF} 7, \mathrm{U} 251: \\
\mathrm{CC}_{50}>8 \mu \mathrm{M}^{100}\end{array}$ \\
\hline 83 & $\mathrm{HCV}$ & Luciferase assay in Huh-7.5 cells & $\begin{array}{l}\mathrm{EC}_{50} \\
2.5 \mu \mathrm{M}^{101}\end{array}$ & $\begin{array}{l}\text { Huh-7.5: } \mathrm{CC}_{50} 23.22 \\
\mu \mathrm{M}^{101}\end{array}$ & \\
\hline 84 & $\mathrm{HCV}$ & Luciferase assay in Huh-7.5 cells & $\begin{array}{l}\mathrm{EC}_{50} \\
>5 \mu \mathrm{M}^{102}\end{array}$ & $\begin{array}{l}\text { Huh-7.5: } \mathrm{CC}_{50}>10 \\
\mu \mathrm{M}^{102}\end{array}$ & \\
\hline \multirow[t]{2}{*}{85} & DENV & Plaque assay in MDDC cells & $\begin{array}{l}\mathrm{EC}_{50} \\
3.5 \mu \mathrm{M}^{103}\end{array}$ & $\begin{array}{l}\text { MDDC: } \mathrm{CC}_{50}>20 \\
\mu \mathrm{M}^{103}\end{array}$ & \\
\hline & DENV-2 & Luciferase assay in Huh-7.5 cells & $\begin{array}{l}\mathrm{EC}_{50} \\
0.86 \mu \mathrm{M}^{103}\end{array}$ & $\begin{array}{l}\text { Huh-7.5: } \mathrm{CC}_{50}>25 \\
\mu \mathrm{M}^{103}\end{array}$ & \\
\hline 86 & DENV-2 & Luciferase assay in Huh-7.5 cells & $\mathrm{EC}_{50} 1.0 \mu \mathrm{M}^{104}$ & $\begin{array}{l}\text { Huh-7.5: } \mathrm{CC}_{50}>10 \\
\mu \mathrm{M}^{104}\end{array}$ & \\
\hline \multirow[t]{2}{*}{87} & EBOV & $\begin{array}{l}\text { Immunofluorescence assays in Huh-7.5 } \\
\text { cells }\end{array}$ & $\mathrm{EC}_{50} 1.59 \mu \mathrm{M}^{105}$ & $\begin{array}{l}\text { Huh-7.5: } \mathrm{CC}_{50}>10 \\
\mu \mathrm{M}^{105}\end{array}$ & \\
\hline & DENV & Plaque assay in MDDC cells & $\mathrm{EC}_{50} 0.042 \mu \mathrm{M}^{105}$ & $\begin{array}{l}\text { MDDC: } \mathrm{CC}_{50}>20 \\
\mu \mathrm{M}^{105}\end{array}$ & \\
\hline A-443654 (88) & HBV & DNA and RNA analyzed by Southern and & $50 \%$ inhibition @ & HepG2: No toxicity at & \\
\hline
\end{tabular}




\begin{tabular}{|c|c|c|c|c|c|}
\hline & & Northern blotting using HepG2 cells & $1 \mu \mathrm{M}^{106}$ & 0.2 and $1 \mu \mathrm{M}^{106}$ & \\
\hline $\begin{array}{l}\text { Tyrphostin A9 } \\
\text { (89) }\end{array}$ & RABV & $\begin{array}{l}\text { Flow } \\
\text { cytometry assay in BSR cells }\end{array}$ & $\mathrm{EC}_{50} 0.9 \mu \mathrm{M}^{107}$ & BSR: $\mathrm{CC}_{50} 150 \mu \mathrm{M}^{107}$ & \\
\hline Rottlerin (90) & RABV & Flow cytometry assay in BSR cells & $\mathrm{EC}_{50} 1.0 \mu \mathrm{M}^{107}$ & BSR: $\mathrm{CC}_{50} 100 \mu \mathrm{M}^{107}$ & \\
\hline 91 & $\begin{array}{l}\text { DENV-2/ } \\
\text { ZIKV }\end{array}$ & $\begin{array}{l}\text { Immunofluorescence assay (IFA) and the } \\
\text { plaque-forming assay } \\
(\mathrm{PFA}) \text { in } \mathrm{BE}(2) \mathrm{C} \text { and } \mathrm{HMC} 3 \text { cells }\end{array}$ & $\begin{array}{l}\mathrm{EC}_{50} \\
1.52 / 1.91 \mu \mathrm{M}^{108}\end{array}$ & $\begin{array}{l}\mathrm{BE}(2) \mathrm{C}: \mathrm{CC}_{50}>12.5 \\
\mu \mathrm{M}^{108}\end{array}$ & \\
\hline BF738735 (92) & $\mathrm{HCV}$ & $\begin{array}{l}\text { luciferase signal and qRT-PCR using Huh7 } \\
\text { cells }\end{array}$ & $\begin{array}{l}\mathrm{EC}_{50} \\
0.1-9.3 \mu \mathrm{M}^{109}\end{array}$ & Huh7: $\mathrm{CC}_{50}>30 \mu \mathrm{M}^{109}$ & \\
\hline Enviroxime (93) & $\mathrm{HCV}$ & $\begin{array}{l}\text { luciferase signal and qRT-PCR using Huh7 } \\
\text { cells }\end{array}$ & $\begin{array}{l}\mathrm{EC}_{50} \\
0.2-2.3 \mu \mathrm{M}^{109}\end{array}$ & Huh7: $\mathrm{CC}_{50} 25 \mu \mathrm{M}^{109}$ & \\
\hline PIK-93 (94) & $\mathrm{HCV}$ & $\begin{array}{l}\text { luciferase signal and qRT-PCR using Huh7 } \\
\text { cells }\end{array}$ & $\begin{array}{l}\mathrm{EC}_{50} \\
0.17-5.8 \mu \mathrm{M}^{109}\end{array}$ & Huh7: $\mathrm{CC}_{50} 8.1 \mu \mathrm{M}^{109}$ & \\
\hline LY294002 (95) & ZEBOV & No. of plaques counted using Vero E6 cells & $\begin{array}{l}10 \text { fold reduction } \\
\text { in virus titer @ } 50\end{array}$ & & $\begin{array}{l}\text { 293T: } \mathrm{CC}_{50}>20 \\
\mu \mathrm{M}^{63}\end{array}$ \\
\hline
\end{tabular}

Page S19 


\begin{tabular}{|c|c|c|c|c|}
\hline & & & $\mu \mathrm{M}^{110}$ & \\
\hline & JUNV & Plaque assay in Vero and BHK-21 cells & $\begin{array}{l}5 \text { fold reduction } \\
\text { in virus titer @ } 10 \\
\mu \mathrm{M}^{111}\end{array}$ & $\begin{array}{l}\text { Vero and BHK-21: } \\
\mathrm{CC}_{50}>10 \mu \mathrm{M}^{111}\end{array}$ \\
\hline M85 (96) & $\begin{array}{l}\text { IAV/ } \\
\text { IBV/ HCV/ } \\
\text { RV }\end{array}$ & $\begin{array}{l}\text { Immunofluorescence assay in } \\
\text { A549/MDCK/Huh 7.5.1/HeLa cells }\end{array}$ & $\begin{array}{l}\mathrm{IC}_{50} \\
0.35 / 0.40 / 0.76 / 0.0 \\
5 \mu \mathrm{M}^{112}\end{array}$ & $\begin{array}{l}\text { A549, MDCK, Huh } \\
\text { 7.5.1, HeLa: } \mathrm{CC}_{50}>50 \\
\mu \mathrm{M}^{112}\end{array}$ \\
\hline 97 & $\begin{array}{l}\text { CVB3/ } \\
\text { HRVM/ } \\
\text { HCV1b/ } \\
\text { HCV2a }\end{array}$ & $\begin{array}{l}\text { Cytopathic effect (CPE) inhibition assay in } \\
\text { HeLa cells }\end{array}$ & $\begin{array}{l}\mathrm{EC}_{50} \\
0.14 / 1.03 / 0.08 / 10 . \\
6 \mu \mathrm{M}^{113}\end{array}$ & HeLa: $\mathrm{CC}_{50}>50 \mu \mathrm{M}^{113}$ \\
\hline 98 & $\begin{array}{l}\text { CVB3/ } \\
\text { HRV-1/ } \\
\text { HCV1b/ } \\
\text { HCV 2a }\end{array}$ & $\begin{array}{l}\text { Cytopathic effect (CPE) inhibition assay in } \\
\text { HeLa cells }\end{array}$ & $\begin{array}{l}\mathrm{EC}_{50} \\
58 / 75 / 29 / 1440 \\
\mathrm{nM}^{114}\end{array}$ & $\begin{array}{l}\text { HeLa: } \mathrm{CC}_{50} 18.3 \\
\mu \mathrm{M}^{114}\end{array}$ \\
\hline SKI II (99) & MV & $\begin{array}{l}\text { Flow cytometry using human primary } \\
\text { PBL/BJAB cells }\end{array}$ & $\begin{array}{l}>75 \% \text { inhibition } \\
\text { @ } 1 \mu \mathrm{M}^{115}\end{array}$ & $\begin{array}{l}\text { PBL, BJAB: } \mathrm{CC}_{50}>5 \\
\mu \mathrm{M}^{115}\end{array}$ \\
\hline
\end{tabular}




\section{REFERENCES CITED IN SUPPORTING INFORMATION:}

1. Cruz, D. J.; Bonotto, R. M.; Gomes, R. G.; da Silva, C. T.; Taniguchi, J. B.; No, J. H.; Lombardot, B.; Schwartz, O.; Hansen, M. A.; Freitas-Junior, L. H. Identification of novel compounds inhibiting chikungunya virus-induced cell death by high throughput screening of a kinase inhibitor library. PLoS Negl. Trop. Dis. 2013, 7, e2471.

2. Cruz, D. J.; Koishi, A. C.; Taniguchi, J. B.; Li, X.; Milan Bonotto, R.; No, J. H.; Kim, K. H.; Baek, S.; Kim, H. Y.; Windisch, M. P.; Pamplona Mosimann, A. L.; de Borba, L.; Liuzzi, M.; Hansen, M. A.; Duarte dos Santos, C. N.; Freitas-Junior, L. H. High content screening of a kinase-focused library reveals compounds broadly-active against dengue viruses. PLoS Negl. Trop. Dis. 2013, 7, e2073.

3. Shum, D.; Smith, J. L.; Hirsch, A. J.; Bhinder, B.; Radu, C.; Stein, D. A.; Nelson, J. A.; Früh, K.; Djaballah, H. High-content assay to identify inhibitors of dengue virus infection. Assay Drug Dev. Technol. 2010, 8, 553-570.

4. Viegas, D. J.; Edwards, T. G.; Bloom, D. C.; Abreu, P. A. Virtual screening identified compounds that bind to cyclin dependent kinase 2 and prevent herpes simplex virus type 1 replication and reactivation in neurons. Antiviral Res. 2019, 172, 104621.

5. Xu, M.; Lee, E. M.; Wen, Z.; Cheng, Y.; Huang, W. K.; Qian, X.; Tcw, J.; Kouznetsova, J.; Ogden, S. C.; Hammack, C.; Jacob, F.; Nguyen, H. N.; Itkin, M.; Hanna, C.; Shinn, P.; Allen, C.; Michael, S. G.; Simeonov, A.; Huang, W.; Christian, K. M.; Goate, A.; Brennand, K. J.; Huang, R.; Xia, M.; Ming, G. L.; Zheng, W.; Song, H.; Tang, H. Identification of small-molecule inhibitors of Zika virus infection and induced neural cell death via a drug repurposing screen. Nat. Med. 2016, 22, 1101-1107. 
6. Emert-Sedlak, L. A.; Narute, P.; Shu, S. T.; Poe, J. A.; Shi, H.; Yanamala, N.; Alvarado, J. J.; Lazo, J. S.; Yeh, J. I.; Johnston, P. A.; Smithgall, T. E. Effector kinase coupling enables high-throughput screens for direct HIV-1 Nef antagonists with antiretroviral activity. Chem. Biol. 2013, 20, 82-91.

7. Perwitasari, O.; Yan, X.; O'Donnell, J.; Johnson, S.; Tripp, R. A. Repurposing kinase inhibitors as antiviral agents to control influenza a virus replication. Assay Drug. Dev. Technol. 2015, 13, 638-649.

8. Chao, S. H.; Fujinaga, K.; Marion, J. E.; Taube, R.; Sausville, E. A.; Senderowicz, A. M.; Peterlin, B. M.; Price, D. H. Flavopiridol inhibits P-TEFb and blocks HIV-1 replication. J. Biol. Chem. 2000, 275, 28345-28348.

9. Dyall, J.; Coleman, C. M.; Hart, B. J.; Venkataraman, T.; Holbrook, M. R.; Kindrachuk, J.; Johnson, R. F.; Olinger, G. G., Jr.; Jahrling, P. B.; Laidlaw, M.; Johansen, L. M.; LearRooney, C. M.; Glass, P. J.; Hensley, L. E.; Frieman, M. B. Repurposing of clinically developed drugs for treatment of Middle East respiratory syndrome coronavirus infection. Antimicrob. Agents Chemother. 2014, 58, 4885-4893.

10. Nelson, E. A.; Dyall, J.; Hoenen, T.; Barnes, A. B.; Zhou, H.; Liang, J. Y.; Michelotti, J.; Dewey, W. H.; DeWald, L. E.; Bennett, R. S.; Morris, P. J.; Guha, R.; Klumpp-Thomas, C.; McKnight, C.; Chen, Y. C.; Xu, X.; Wang, A.; Hughes, E.; Martin, S.; Thomas, C.; Jahrling, P. B.; Hensley, L. E.; Olinger, G. G., Jr.; White, J. M. The phosphatidylinositol3-phosphate 5-kinase inhibitor apilimod blocks filoviral entry and infection. PLoS Negl. Trop. Dis. 2017, 11, e0005540.

11. Riva, L.; Yuan, S.; Yin, X.; Martin-Sancho, L.; Matsunaga, N.; Burgstaller-Muehlbacher, S.; Pache, L.; De Jesus, P. P.; Hull, M. V.; Chang, M.; Chan, J. F.; Cao, J.; Poon, V. K.; 
Herbert, K.; Nguyen, T. T.; Pu, Y.; Nguyen, C.; Rubanov, A.; Martinez-Sobrido, L.; Liu, W. C.; Miorin, L.; White, K. M.; Johnson, J. R.; Benner, C.; Sun, R.; Schultz, P. G.; Su, A.; Garcia-Sastre, A.; Chatterjee, A. K.; Yuen, K. Y.; Chanda, S. K. A large-scale drug repositioning survey for SARS-CoV-2 antivirals. BioRxiv 2020, DOI: 10.1101/2020.04.16.044016.

12. Garcia, G.; Sharma, A.; Ramaiah, A.; Sen, C.; Kohn, D.; Gomperts, B.; Svendsen, C. N.; Damoiseaux, R. D.; Arumugaswami, V. Antiviral drug screen of kinase inhibitors identifies cellular signaling pathways critical for SARS-COV-2 replication. BioRxiv 2020, DOI: $10.1101 / 2020.06 .24 .150326$.

13. Mirabelli, C.; Wotring, J. W.; Zhang, C. J.; McCarty, S. M.; Fursmidt, R.; Frum, T.; Kadambi, N. S.; Amin, A. T.; O'Meara, T. R.; Pretto, C. D.; Spence, J. R.; Huang, J.; Alysandratos, K. D.; Kotton, D. N.; Handelman, S. K.; Wobus, C. E.; Weatherwax, K. J.; Mashour, G. A.; O'Meara, M. J.; Sexton, J. Z. Morphological cell profiling of SARSCOV-2 infection identifies drug repurposing candidates for COVID-19. BioRxiv 2020, Doi: $10.1101 / 2020.05 .27 .117184$.

14. Sun, J.; Yogarajah, T.; Lee, R. C. H.; Kaur, P.; Inoue, M.; Tan, Y. W.; Chu, J. J. H. Drug repurposing of pyrimidine analogs as potent antiviral compounds against human enterovirus A71 infection with potential clinical applications. Sci. Rep. 2020, 10, 8159.

15. Lupberger, J.; Zeisel, M. B.; Xiao, F.; Thumann, C.; Fofana, I.; Zona, L.; Davis, C.; Mee, C. J.; Turek, M.; Gorke, S.; Royer, C.; Fischer, B.; Zahid, M. N.; Lavillette, D.; Fresquet, J.; Cosset, F. L.; Rothenberg, S. M.; Pietschmann, T.; Patel, A. H.; Pessaux, P.; Doffoël, M.; Raffelsberger, W.; Poch, O.; McKeating, J. A.; Brino, L.; Baumert, T. F. EGFR and 
EphA2 are host factors for hepatitis $\mathrm{C}$ virus entry and possible targets for antiviral therapy. Nat.Med. 2011, 17, 589-595.

16. de Wispelaere, M.; LaCroix, A. J.; Yang, P. L. The small molecules AZD0530 and dasatinib inhibit dengue virus RNA replication via Fyn kinase. J Virol 2013, 87, 73677381.

17. Neveu, G.; Barouch-Bentov, R.; Ziv-Av, A.; Gerber, D.; Jacob, Y.; Einav, S. Identification and targeting of an interaction between a tyrosine motif within hepatitis $\mathrm{C}$ virus core protein and AP2M1 essential for viral assembly. PLoS Pathog. 2012, 8, e1002845.

18. Bekerman, E.; Neveu, G.; Shulla, A.; Brannan, J.; Pu, S. Y.; Wang, S.; Xiao, F.; Barouch-Bentov, R.; Bakken, R. R.; Mateo, R.; Govero, J.; Nagamine, C. M.; Diamond, M. S.; De Jonghe, S.; Herdewijn, P.; Dye, J. M.; Randall, G.; Einav, S. Anticancer kinase inhibitors impair intracellular viral trafficking and exert broad-spectrum antiviral effects. J. Clin. Invest. 2017, 127, 1338-1352.

19. Neveu, G.; Ziv-Av, A.; Barouch-Bentov, R.; Berkerman, E.; Mulholland, J.; Einav, S. AAK1 and GAK regulate hepatitis $\mathrm{C}$ virus entry and are potential drug targets. J. Virol. 2015, 89, 4387-4404.

20. Pu, S. Y.; Xiao, F.; Schor, S.; Bekerman, E.; Zanini, F.; Barouch-Bentov, R.; Nagamine, C. M.; Einav, S. Feasibility and biological rationale of repurposing sunitinib and erlotinib for dengue treatment. Antiviral Res. 2018, 155, 67-75.

21. Langhammer, S.; Koban, R.; Yue, C.; Ellerbrok, H. Inhibition of poxvirus spreading by the anti-tumor drug Gefitinib (Iressa). Antiviral Res. 2011, 89, 64-70. 
22. Himmelsbach, K.; Sauter, D.; Baumert, T. F.; Ludwig, L.; Blum, H. E.; Hildt, E. New aspects of an anti-tumour drug: sorafenib efficiently inhibits HCV replication. Gut 2009, $58,1644-1653$.

23. Gao, M.; Duan, H.; Liu, J.; Zhang, H.; Wang, X.; Zhu, M.; Guo, J.; Zhao, Z.; Meng, L.; Peng, Y. The multi-targeted kinase inhibitor sorafenib inhibits enterovirus 71 replication by regulating IRES-dependent translation of viral proteins. Antiviral Res. 2014, 106, 8085.

24. Kindrachuk, J.; Ork, B.; Hart, B. J.; Mazur, S.; Holbrook, M. R.; Frieman, M. B.; Traynor, D.; Johnson, R. F.; Dyall, J.; Kuhn, J. H.; Olinger, G. G.; Hensley, L. E.; Jahrling, P. B. Antiviral potential of ERK/MAPK and PI3K/AKT/mTOR signaling modulation for middle east respiratory syndrome coronavirus infection as identified by temporal kinome analysis. Antimicrob. Agents Chemother. 2015, 59, 1088-1099.

25. Benedict, A.; Bansal, N.; Senina, S.; Hooper, I.; Lundberg, L.; de la Fuente, C.; Narayanan, A.; Gutting, B.; Kehn-Hall, K. Repurposing FDA-approved drugs as therapeutics to treat Rift Valley fever virus infection. Front. Microbiol. 2015, 6, 676.

26. Lundberg, L.; Brahms, A.; Hooper, I.; Carey, B.; Lin, S. C.; Dahal, B.; Narayanan, A.; Kehn-Hall, K. Repurposed FDA-Approved drug sorafenib reduces replication of Venezuelan equine encephalitis virus and other alphaviruses. Antiviral Res. 2018, 157 , 57-67.

27. Marosi, A.; Forgách, P.; Gyuranecz, M.; Sulyok, K. M.; Bakonyi, T. Evaluation of in vitro inhibitory potential of type-I interferons and different antiviral compounds on rabies virus replication. Vaccine 2019, 37, 4663-4672. 
28. Lesch, M.; Luckner, M.; Meyer, M.; Weege, F.; Gravenstein, I.; Raftery, M.; Sieben, C.; Martin-Sancho, L.; Imai-Matsushima, A.; Welke, R. W.; Frise, R.; Barclay, W.; Schönrich, G.; Herrmann, A.; Meyer, T. F.; Karlas, A. RNAi-based small molecule repositioning reveals clinically approved urea-based kinase inhibitors as broadly active antivirals. PLoS Pathog. 2019, 15, e1007601.

29. Garcia-Vidal, E.; Badia, R.; Pujantell, M.; Castellví, M.; Felip, E.; Clotet, B.; RiveiraMuñoz, E.; Ballana, E.; Esté, J. A. Dual effect of the broad spectrum kinase inhibitor midostaurin in acute and latent HIV-1 infection. Antiviral Res. 2019, 168, 18-27.

30. Stebbing, J.; Krishnan, V.; de Bono, S.; Ottaviani, S.; Casalini, G.; Richardson, P. J.; Monteil, V.; Lauschke, V. M.; Mirazimi, A.; Youhanna, S.; Tan, Y. J.; Baldanti, F.; Sarasini, A.; Terres, J. A. R.; Nickoloff, B. J.; Higgs, R. E.; Rocha, G.; Byers, N. L.; Schlichting, D. E.; Nirula, A.; Cardoso, A.; Corbellino, M.; Sacco Baricitinib Study, G. Mechanism of baricitinib supports artificial intelligence-predicted testing in COVID-19 patients. EMBO Mol. Med. 2020, 12, e12697.

31. Gavegnano, C.; Detorio, M.; Montero, C.; Bosque, A.; Planelles, V.; Schinazi, R. F. Ruxolitinib and tofacitinib are potent and selective inhibitors of HIV-1 replication and virus reactivation in vitro. Antimicrob. Agents Chemother. 2014, 58, 1977-1986.

32. Haile, W. B.; Gavegnano, C.; Tao, S.; Jiang, Y.; Schinazi, R. F.; Tyor, W. R. The Janus kinase inhibitor ruxolitinib reduces HIV replication in human macrophages and ameliorates HIV encephalitis in a murine model. Neurobiol. Dis. 2016, 92, 137-143.

33. Waldman, W. J.; Knight, D. A.; Blinder, L.; Shen, J.; Lurain, N. S.; Miller, D. M.; Sedmak, D. D.; Williams, J. W.; Chong, A. S. Inhibition of cytomegalovirus in vitro and 
in vivo by the experimental immunosuppressive agent leflunomide. Intervirology 1999, 42, 412-418.

34. Jeffers-Francis, L. K.; Burger-Calderon, R.; Webster-Cyriaque, J. Effect of Leflunomide, Cidofovir and Ciprofloxacin on replication of BKPyV in a salivary gland in vitro culture system. Antiviral Res. 2015, 118, 46-55.

35. Wang, J.; Sun, J.; Hu, J.; Wang, C.; Prinz, R. A.; Peng, D.; Liu, X.; Xu, X. A77 1726, the active metabolite of the anti-rheumatoid arthritis drug leflunomide, inhibits influenza A virus replication in vitro and in vivo by inhibiting the activity of Janus kinases. FASEB $J$ 2020, 34, 10132-10145.

36. Sepulveda, C. S.; Garcia, C. C.; Damonte, E. B. Antiviral activity of A771726, the active metabolite of leflunomide, against Junin virus. J. Med. Virol. 2018, 90, 819-827.

37. Li, C. J.; Jiang, C.; Liu, Y.; Bell, T.; Ma, W.; Ye, Y.; Huang, S.; Guo, H.; Zhang, H.; Wang, L.; Wang, J.; Nomie, K.; Zhang, L.; Wang, M. Pleiotropic Action of Novel Bruton's Tyrosine Kinase Inhibitor BGB-3111 in Mantle Cell Lymphoma. Mol. Cancer Ther. 2019, 18, 267-277.

38. Zhu, Z.; Ling, L.; Qi, L.; Chong, Y.; Xue, L. Bruton's Tyrosine Kinase (BTK) Inhibitor (Ibrutinib)-Suppressed Migration and Invasion of Prostate Cancer. OncoTargets Ther. 2020, 13, 4113-4122.

39. Pauls, E.; Badia, R.; Torres-Torronteras, J.; Ruiz, A.; Permanyer, M.; Riveira-Muñoz, E.; Clotet, B.; Marti, R.; Ballana, E.; Esté, J. A. Palbociclib, a selective inhibitor of cyclindependent kinase4/6, blocks HIV-1 reverse transcription through the control of sterile $\alpha$ motif and HD domain-containing protein-1 (SAMHD1) activity. AIDS 2014, 28, 22132222. 
40. Badia, R.; Angulo, G.; Riveira-Muñoz, E.; Pujantell, M.; Puig, T.; Ramirez, C.; TorresTorronteras, J.; Martí, R.; Pauls, E.; Clotet, B.; Ballana, E.; Esté, J. A. Inhibition of herpes simplex virus type 1 by the CDK6 inhibitor PD-0332991 (palbociclib) through the control of SAMHD1. J. Antimicrob. Chemother. 2016, 71, 387-394.

41. Schräder, T.; Dudek, S. E.; Schreiber, A.; Ehrhardt, C.; Planz, O.; Ludwig, S. The clinically approved MEK inhibitor Trametinib efficiently blocks influenza A virus propagation and cytokine expression. Antiviral Res. 2018, 157, 80-92.

42. Haasbach, E.; Hartmayer, C.; Planz, O. Combination of MEK inhibitors and oseltamivir leads to synergistic antiviral effects after influenza A virus infection in vitro. Antiviral Res. 2013, 98, 319-324.

43. Mohr, E. L.; McMullan, L. K.; Lo, M. K.; Spengler, J. R.; Bergeron, É.; Albariño, C. G.; Shrivastava-Ranjan, P.; Chiang, C. F.; Nichol, S. T.; Spiropoulou, C. F.; Flint, M. Inhibitors of cellular kinases with broad-spectrum antiviral activity for hemorrhagic fever viruses. Antiviral Res. 2015, 120, 40-47.

44. Yang, H.; Kim, S. K.; Kim, M.; Reche, P. A.; Morehead, T. J.; Damon, I. K.; Welsh, R. M.; Reinherz, E. L. Antiviral chemotherapy facilitates control of poxvirus infections through inhibition of cellular signal transduction. J. Clin. Invest. 2005, 115, 379-387.

45. Strange, D. P.; Jiyarom, B.; Pourhabibi Zarandi, N.; Xie, X.; Baker, C.; Sadri-Ardekani, H.; Shi, P. Y.; Verma, S. Axl promotes zika virus entry and modulates the antiviral state of human sertoli cells. mBio 2019, 10, e01372-19.

46. Shin, J. S.; Jung, E.; Kim, M.; Baric, R. S.; Go, Y. Y. Saracatinib inhibits middle east respiratory syndrome-coronavirus replication in vitro. Viruses 2018, 10, 283. 
47. Chuang, H. Y.; Su, Y. K.; Liu, H. W.; Chen, C. H.; Chiu, S. C.; Cho, D. Y.; Lin, S. Z.; Chen, Y. S.; Lin, C. M. Preclinical Evidence of STAT3 Inhibitor Pacritinib Overcoming Temozolomide Resistance via Downregulating miR-21-Enriched Exosomes from M2 Glioblastoma-Associated Macrophages. J. Clin. Med. 2019, 8, 959.

48. D'Aiuto, L.; Williamson, K.; Dimitrion, P.; McNulty, J.; Brown, C. E.; Dokuburra, C. B.; Nielsen, A. J.; Lin, W. J.; Piazza, P.; Schurdak, M. E.; Wood, J.; Yolken, R. H.; Kinchington, P. R.; Bloom, D. C.; Nimgaonkar, V. L. Comparison of three cell-based drug screening platforms for HSV-1 infection. Antiviral Res. 2017, 142, 136-140.

49. Yeh, Y. J.; Jenike, K. M.; Calvi, R. M.; Chiarella, J.; Hoh, R.; Deeks, S. G.; Ho, Y. C. Filgotinib suppresses HIV-1-driven gene transcription by inhibiting HIV-1 splicing and T cell activation. J. Clin. Invest. 2020, 130, 4969-4984.

50. Lai, P.-C.; Fang, T.-C.; Cheng, C.-C.; Chiu, T. H.; Huang, Y.-T. Lestaurtinib is Cytotoxic to Oxaliplatin-resistant Transitional Cell Carcinoma Cell Line T24 In Vitro. Tzu Chi Med. J. 2010, 22, 125-130.

51. Agbottah, E.; de La Fuente, C.; Nekhai, S.; Barnett, A.; Gianella-Borradori, A.; Pumfery, A.; Kashanchi, F. Antiviral activity of CYC202 in HIV-1-infected cells. J. Biol. Chem. 2005, 280, 3029-3042.

52. Taylor, S. L.; Kinchington, P. R.; Brooks, A.; Moffat, J. F. Roscovitine, a cyclindependent kinase inhibitor, prevents replication of varicella-zoster virus. J. Virol. 2004, $78,2853-2862$.

53. Huang, Q.; Zhong, Y.; Li, J.; Ye, Y.; Wu, W.; Chen, L.; Feng, M.; Yang, J.; Liu, S. Kinase inhibitor roscovitine as a PB2 cap-binding inhibitor against influenza a virus replication. Biochem. Biophys. Res. Commun. 2020, 526, 1143-1149. 
54. Bresnahan, W. A.; Boldogh, I.; Chi, P.; Thompson, E. A.; Albrecht, T. Inhibition of cellular Cdk2 activity blocks human cytomegalovirus replication. Virology 1997, 231, 239-247.

55. Yamamoto, M.; Onogi, H.; Kii, I.; Yoshida, S.; Iida, K.; Sakai, H.; Abe, M.; Tsubota, T.; Ito, N.; Hosoya, T.; Hagiwara, M. CDK9 inhibitor FIT-039 prevents replication of multiple DNA viruses. J. Clin. Invest. 2014, 124, 3479-3488.

56. Tanaka, T.; Okuyama-Dobashi, K.; Murakami, S.; Chen, W.; Okamoto, T.; Ueda, K.; Hosoya, T.; Matsuura, Y.; Ryo, A.; Tanaka, Y.; Hagiwara, M.; Moriishi, K. Inhibitory effect of CDK9 inhibitor FIT-039 on hepatitis B virus propagation. Antiviral Res. 2016, $133,156-164$.

57. Hou, J.; Zhang, Z.; Huang, Q.; Yan, J.; Zhang, X.; Yu, X.; Tan, G.; Zheng, C.; Xu, F.; He, S. Antiviral activity of PHA767491 against human herpes simplex virus in vitro and in vivo. BMC Infect. Dis. 2017, 17, 217.

58. Vargas, B.; Giacobbi, N. S.; Sanyal, A.; Venkatachari, N. J.; Han, F.; Gupta, P.; SluisCremer, N. Inhibitors of Signaling Pathways That Block Reversal of HIV-1 Latency. Antimicrob. Agents Chemother. 2019, 63, e01744-18.

59. Haasbach, E.; Müller, C.; Ehrhardt, C.; Schreiber, A.; Pleschka, S.; Ludwig, S.; Planz, O. The MEK-inhibitor CI-1040 displays a broad anti-influenza virus activity in vitro and provides a prolonged treatment window compared to standard of care in vivo. Antiviral Res. 2017, 142, 178-184.

60. Denisova, O. V.; Söderholm, S.; Virtanen, S.; Von Schantz, C.; Bychkov, D.; Vashchinkina, E.; Desloovere, J.; Tynell, J.; Ikonen, N.; Theisen, L. L.; Nyman, T. A.; Matikainen, S.; Kallioniemi, O.; Julkunen, I.; Muller, C. P.; Saelens, X.; Verkhusha, V. 
V.; Kainov, D. E. Akt inhibitor MK2206 prevents influenza pH1N1 virus infection in vitro. Antimicrob. Agents Chemother. 2014, 58, 3689-3696.

61. Zhou, F.; Wan, Q.; Lu, J.; Chen, Y.; Lu, G.; He, M. L. Pim1 impacts enterovirus A71 replication and represents a potential target in antiviral therapy. iScience 2019, 19, 715727.

62. Pohl, M. O.; von Recum-Knepper, J.; Rodriguez-Frandsen, A.; Lanz, C.; Yángüez, E.; Soonthornvacharin, S.; Wolff, T.; Chanda, S. K.; Stertz, S. Identification of Polo-like kinases as potential novel drug targets for influenza A virus. Sci. Rep. 2017, 7, 8629.

63. Urata, S.; Ngo, N.; de la Torre, J. C. The PI3K/Akt pathway contributes to arenavirus budding. J. Virol. 2012, 86, 4578-4585.

64. Xia, C.; Seo, Y. J.; Studstill, C. J.; Vijayan, M.; Wolf, J. J.; Hahm, B. Transient inhibition of sphingosine kinases confers protection to influenza A virus infected mice. Antiviral Res. 2018, 158, 171-177.

65. Lewis, C. S.; Voelkel-Johnson, C.; Smith, C. D. Suppression of c-Myc and RRM2 expression in pancreatic cancer cells by the sphingosine kinase-2 inhibitor ABC294640. Oncotarget 2016, 7, 60181-60192.

66. Kang, Y.-L.; Chou, Y.-Y.; Rothlauf, P. W.; Liu, Z.; Soh, T. K.; Cureton, D.; Case, J. B.; Chen, R. E.; Diamond, M. S.; Whelan, S. P. J.; Kirchhausen, T. Inhibition of PIKfyve kinase prevents infection by Zaire ebolavirus and SARS-CoV-2. Proc. Natl. Acad. Sci. USA 2020, 117, 20803-20813.

67. Yue, J.; Lu, Y. Vacuolin-1 as an inhibitor of autophagy and endosomal trafficking and the use thereof for inhibiting tumor progression. WO2015124120A1, February 19, 2014. 2014. 
68. Chan, J. F.; Zhu, Z.; Chu, H.; Yuan, S.; Chik, K. K.; Chan, C. C.; Poon, V. K.; Yip, C. C.; Zhang, X.; Tsang, J. O.; Zou, Z.; Tee, K. M.; Shuai, H.; Lu, G.; Yuen, K. Y. The celecoxib derivative kinase inhibitor AR-12 (OSU-03012) inhibits Zika virus via downregulation of the PI3K/Akt pathway and protects Zika virus-infected A129 mice: A hosttargeting treatment strategy. Antiviral Res. 2018, 160, 38-47.

69. Stantchev, T. S.; Markovic, I.; Telford, W. G.; Clouse, K. A.; Broder, C. C. The tyrosine kinase inhibitor genistein blocks HIV-1 infection in primary human macrophages. Virus Res. 2007, 123, 178-189.

70. Yura, Y.; Yoshida, H.; Sato, M. Inhibition of herpes simplex virus replication by genistein, an inhibitor of protein-tyrosine kinase. Arch. Virol. 1993, 132, 451-461.

71. Vela, E. M.; Bowick, G. C.; Herzog, N. K.; Aronson, J. F. Genistein treatment of cells inhibits arenavirus infection. Antiviral Res. 2008, 77, 153-156.

72. LeCher, J. C.; Diep, N.; Krug, P. W.; Hilliard, J. K. Genistein has antiviral activity against herpes $\mathrm{B}$ virus and acts synergistically with antiviral treatments to reduce effective dose. Viruses 2019, 11, 499.

73. Clark, M. J.; Miduturu, C.; Schmidt, A. G.; Zhu, X.; Pitts, J. D.; Wang, J.; Potisopon, S.; Zhang, J.; Wojciechowski, A.; Hann Chu, J. J.; Gray, N. S.; Yang, P. L. GNF-2 inhibits dengue virus by targeting abl kinases and the viral e protein. Cell Chem. Biol. 2016, 23, 443-452.

74. Song, G. J.; Rahman, M. H.; Jha, M. K.; Gupta, D. P.; Park, S. H.; Kim, J. H.; Lee, S. H.; Lee, I. K.; Sim, T.; Bae, Y. C.; Lee, W. H.; Suk, K. A Bcr-Abl Inhibitor GNF-2 Attenuates Inflammatory Activation of Glia and Chronic Pain. Front. Pharmacol. 2019, $10,543$. 
75. Reeves, P. M.; Bommarius, B.; Lebeis, S.; McNulty, S.; Christensen, J.; Swimm, A.; Chahroudi, A.; Chavan, R.; Feinberg, M. B.; Veach, D.; Bornmann, W.; Sherman, M.; Kalman, D. Disabling poxvirus pathogenesis by inhibition of Abl-family tyrosine kinases. Nat. Med. 2005, 11, 731-739.

76. Hrabák, A.; Bökönyi, G.; Orfi, L.; Bajor, T.; Kéri, G. Comparison of the cytotoxic effects of receptor tyrosine kinase inhibitors on macrophage functions; possible side effects in the immune defense. Immunol. Lett. 2006, 107, 169-75.

77. Rausch, K.; Hackett, B. A.; Weinbren, N. L.; Reeder, S. M.; Sadovsky, Y.; Hunter, C. A.; Schultz, D. C.; Coyne, C. B.; Cherry, S. Screening bioactives reveals nanchangmycin as a broad spectrum antiviral active against zika virus. Cell Rep. 2017, 18, 804-815.

78. Hu, Y.; Zhang, J.; Musharrafieh, R.; Hau, R.; Ma, C.; Wang, J. Chemical genomics approach leads to the identification of hesperadin, an aurora b kinase inhibitor, as a broad-spectrum influenza antiviral. Int. J. Mol. Sci. 2017, 18, 1929.

79. Dong, W.; Xie, W.; Liu, Y.; Sui, B.; Zhang, H.; Liu, L.; Tan, Y.; Tong, X.; Fu, Z. F.; Yin, P.; Fang, L.; Peng, G. Receptor tyrosine kinase inhibitors block proliferation of TGEV mainly through p38 mitogen-activated protein kinase pathways. Antiviral Res. 2020, $173,104651$.

80. Kumar, N.; Liang, Y.; Parslow, T. G.; Liang, Y. Receptor tyrosine kinase inhibitors block multiple steps of influenza a virus replication. J Virol 2011, 85, 2818-2827.

81. Sasaki, Y.; Kakisaka, M.; Chutiwitoonchai, N.; Tajima, S.; Hikono, H.; Saito, T.; Aida, Y. Identification of a novel multiple kinase inhibitor with potent antiviral activity against influenza virus by reducing viral polymerase activity. Biochem. Biophys. Res. Commun. 2014, 450, 49-54. 
82. Strang, B. L. RO0504985 is an inhibitor of CMGC kinase proteins and has anti-human cytomegalovirus activity. Antiviral Res. 2017, 144, 21-26.

83. Iqbal, A.; Suryawanshi, R.; Yadavalli, T.; Volety, I.; Shukla, D. BX795 demonstrates potent antiviral benefits against herpes simplex virus-1 infection of human cell lines. Antiviral Res. 2020, 180, 104814.

84. Hopkins, J.; Yadavalli, T.; Suryawanshi, R.; Qatanani, F.; Volety, I.; Koganti, R.; Iqbal, A.; Shukla, D. In vitro and in vivo activity, tolerability, and mechanism of action of BX795 as an antiviral against herpes simplex virus 2 genital infection. Antimicrob. Agents Chemother. 2020, 64, e00245-20.

85. Bergmann, S.; Elbahesh, H. Targeting the proviral host kinase, FAK, limits influenza a virus pathogenesis and NFkB-regulated pro-inflammatory responses. Virology 2019, 534, 54-63.

86. Zhang, H.; Shao, H.; Golubovskaya, V. M.; Chen, H.; Cance, W.; Adjei, A. A.; Dy, G. K. Efficacy of focal adhesion kinase inhibition in non-small cell lung cancer with oncogenically activated MAPK pathways. Br. J. Cancer 2016, 115, 203-211.

87. Caligiuri, M.; Becker, F.; Murthi, K.; Kaplan, F.; Dedier, S.; Kaufmann, C.; Machl, A.; Zybarth, G.; Richard, J.; Bockovich, N.; Kluge, A.; Kley, N. A Proteome-Wide CDK/CRK-Specific Kinase Inhibitor Promotes Tumor Cell Death in the Absence of Cell Cycle Progression. Chem. Biol. 2005, 12, 1103-1115.

88. Guendel, I.; Agbottah, E. T.; Kehn-Hall, K.; Kashanchi, F. Inhibition of human immunodeficiency virus type-1 by cdk inhibitors. AIDS Res. Ther. 2010, 7, 7. 
89. Moffat, J. F.; McMichael, M. A.; Leisenfelder, S. A.; Taylor, S. L. Viral and cellular kinases are potential antiviral targets and have a central role in varicella zoster virus pathogenesis. Biochim Biophys Acta 2004, 1697, 225-231.

90. Hutterer, C.; Eickhoff, J.; Milbradt, J.; Korn, K.; Zeittrager, I.; Bahsi, H.; Wagner, S.; Zischinsky, G.; Wolf, A.; Degenhart, C.; Unger, A.; Baumann, M.; Klebl, B.; Marschall, M. A novel CDK7 inhibitor of the pyrazolotriazine class exerts broad-spectrum antiviral activity at nanomolar concentrations. Antimicrob. Agents Chemother. 2015, 59, 20622071.

91. Planz, O.; Pleschka, S.; Ludwig, S. MEK-specific inhibitor U0126 blocks spread of Borna disease virus in cultured cells. J. Virol. 2001, 75, 4871-4877.

92. Pleschka, S.; Wolff, T.; Ehrhardt, C.; Hobom, G.; Planz, O.; Rapp, U. R.; Ludwig, S. Influenza virus propagation is impaired by inhibition of the Raf/MEK/ERK signalling cascade. Nature Cell Biol. 2001, 3, 301-305.

93. Ludwig, S.; Wolff, T.; Ehrhardt, C.; Wurzer, W. J.; Reinhardt, J.; Planz, O.; Pleschka, S. MEK inhibition impairs influenza B virus propagation without emergence of resistant variants. FEBS Lett. 2004, 561, 37-43.

94. Droebner, K.; Pleschka, S.; Ludwig, S.; Planz, O. Antiviral activity of the MEK-inhibitor U0126 against pandemic H1N1v and highly pathogenic avian influenza virus in vitro and in vivo. Antiviral Res. 2011, 92, 195-203.

95. Rodríguez, M. E.; Brunetti, J. E.; Wachsman, M. B.; Scolaro, L. A.; Castilla, V. Raf/MEK/ERK pathway activation is required for Junín virus replication. J. Gen. Virol. 2014, 95, 799-805. 
96. Albarnaz, J. D.; De Oliveira, L. C.; Torres, A. A.; Palhares, R. M.; Casteluber, M. C.; Rodrigues, C. M.; Cardozo, P. L.; De Souza, A. M.; Pacca, C. C.; Ferreira, P. C.; Kroon, E. G.; Nogueira, M. L.; Bonjardim, C. A. MEK/ERK activation plays a decisive role in yellow fever virus replication: implication as an antiviral therapeutic target. Antiviral Res. 2014, 111, 82-92.

97. Kang, S.; Song, M. J.; Min, H. Antiviral activity of ginsenoside Rg3 isomers against gammaherpesvirus through inhibition of p38- and JNK-associated pathways. J. Funct. Foods 2018, 40, 219-228.

98. Kono, M.; Tatsumi, K.; Imai, A. M.; Saito, K.; Kuriyama, T.; Shirasawa, H. Inhibition of human coronavirus 229E infection in human epithelial lung cells (L132) by chloroquine: involvement of p38 MAPK and ERK. Antiviral Res. 2008, 77, 150-152.

99. Root, C. N.; Wills, E. G.; McNair, L. L.; Whittaker, G. R. Entry of influenza viruses into cells is inhibited by a highly specific protein kinase c inhibitor. J. Gen. Virol. 2000, 81, $2697-2705$.

100. Zhang, X.; Jia, D.; Ao, J.; Liu, H.; Zang, Y.; Azam, M.; Habib, S. L.; Li, J.; Ruan, X.; Jia, H.; Wang, X.; Li, B. Identification of Bisindolylmaleimide IX as a potential agent to treat drug-resistant BCR-ABL positive leukemia. Oncotarget 2016, 7, 69945-69960.

101. Kovackova, S.; Chang, L.; Bekerman, E.; Neveu, G.; Barouch-Bentov, R.; Chaikuad, A.; Heroven, C.; Šála, M.; De Jonghe, S.; Knapp, S.; Einav, S.; Herdewijn, P. Selective inhibitors of cyclin G associated kinase (GAK) as anti-hepatitis c agents. J. Med. Chem. 2015, 58, 3393-3410.

102. Li, J.; Kovackova, S.; Pu, S.; Rozenski, J.; De Jonghe, S.; Einav, S.; Herdewijn, P. Isothiazolo[4,3-b]pyridines as inhibitors of cyclin $\mathrm{G}$ associated kinase : synthesis, 
structure-activity relationship studies and antiviral activity. MedChemComm 2015, 6, 1666-1672.

103. Pu, S. Y.; Wouters, R.; Schor, S.; Rozenski, J.; Barouch-Bentov, R.; Prugar, L. I.; O'Brien, C. M.; Brannan, J. M.; Dye, J. M.; Herdewijn, P.; De Jonghe, S.; Einav, S. Optimization of isothiazolo[4,3- b]pyridine-based inhibitors of cyclin $\mathrm{G}$ associated kinase (GAK) with broad-spectrum antiviral activity. J. Med. Chem. 2018, 61, 6178-6192.

104. Martinez-Gualda, B.; Pu, S. Y.; Froeyen, M.; Herdewijn, P.; Einav, S.; De Jonghe, S. Structure-activity relationship study of the pyridine moiety of isothiazolo[4,3-b]pyridines as antiviral agents targeting cyclin G-associated kinase. Bioorg. Med. Chem. 2020, 28, 115188.

105. Verdonck, S.; Pu, S.-Y.; Sorrell, F. J.; Elkins, J. M.; Froeyen, M.; Gao, L.-J.; Prugar, L. I.; Dorosky, D. E.; Brannan, J. M.; Barouch-Bentov, R. Synthesis and structure-activity relationships of 3, 5-disubstituted-pyrrolo [2, 3-b] pyridines as inhibitors of adaptorassociated kinase 1 with antiviral activity. J. Med. Chem. 2019, 62, 5810-5831.

106. Jeong, G. U.; Ahn, B. Y. Aurora kinase A promotes hepatitis B virus replication and expression. Antiviral Res. 2019, 170, 104572.

107. Lama, Z.; Gaudin, Y.; Blondel, D.; Lagaudrière-Gesbert, C. Kinase inhibitors tyrphostin 9 and rottlerin block early steps of rabies virus cycle. Antiviral Res. 2019, 168, 51-60.

108. Chen, W. C.; Simanjuntak, Y.; Chu, L. W.; Ping, Y. H.; Lee, Y. L.; Lin, Y. L.; Li, W. S. Benzenesulfonamide derivatives as calcium/calmodulin-dependent protein kinase inhibitors and antiviral agents against dengue and zika virus infections. J. Med. Chem. 2020, 63, 1313-1327. 
109. Delang, L.; Harak, C.; Benkheil, M.; Khan, H.; Leyssen, P.; Andrews, M.; Lohmann, V.; Neyts, J. PI4KIII inhibitor enviroxime impedes the replication of the hepatitis C virus by inhibiting PI3 kinases. J. Antimicrob. Chemother. 2018, 73, 3375-3384.

110. Saeed, M. F.; Kolokoltsov, A. A.; Freiberg, A. N.; Holbrook, M. R.; Davey, R. A. Phosphoinositide-3 kinase-AKT pathway controls cellular entry of ebola virus. PLoS Pathogens 2008, 4, e1000141.

111. Linero, F. N.; Scolaro, L. A. Participation of the phosphatidylinositol 3-kinase/Akt pathway in Junín virus replication in vitro. Virus Res. 2009, 145, 166-170.

112. O'Hanlon, R.; Leyva-Grado, V. H.; Sourisseau, M.; Evans, M. J.; Shaw, M. L. An influenza virus entry inhibitor targets class II PI3 kinase and synergizes with oseltamivir. ACS Infect. Dis. 2019, 5, 1779-1793.

113. Mejdrová, I.; Chalupská, D.; Kögler, M.; Šála, M.; Plačková, P.; Baumlová, A.; Hřebabecký, H.; Procházková, E.; Dejmek, M.; Guillon, R.; Strunin, D.; Weber, J.; Lee, G.; Birkus, G.; Mertlíková-Kaiserová, H.; Boura, E.; Nencka, R. Highly selective phosphatidylinositol 4-kinase IIIB inhibitors and structural insight into their mode of action. J. Med. Chem. 2015, 58, 3767-3793.

114. Mejdrová, I.; Chalupská, D.; Plačková, P.; Müller, C.; Šála, M.; Klíma, M.; Baumlová, A.; Hřebabecký, H.; Procházková, E.; Dejmek, M.; Strunin, D.; Weber, J.; Lee, G.; Matoušová, M.; Mertlíková-Kaiserová, H.; Ziebuhr, J.; Birkus, G.; Boura, E.; Nencka, R. Rational design of novel highly potent and selective phosphatidylinositol 4-kinase IIIB (PI4KB) inhibitors as broad-spectrum antiviral agents and tools for chemical biology. $J$. Med. Chem. 2017, 60, 100-118. 
115. Grafen, A.; Schumacher, F.; Chithelen, J.; Kleuser, B.; Beyersdorf, N.; SchneiderSchaulies, J. Use of acid ceramidase and sphingosine kinase inhibitors as antiviral compounds against measles virus infection of lymphocytes in vitro. Front Cell Dev. Biol. 2019, 7, 218. 